\title{
Stratigraphic record of continental breakup, offshore NW Australia
}

\author{
Matthew T. Reeve $^{1}$ | Craig Magee ${ }^{1,2}$ (1) | Christopher A.-L. Jackson ${ }^{1,3}$ | \\ Rebecca E. Bell ${ }^{1}$ | Ian D. Bastow ${ }^{1}(0$
}

${ }^{1}$ Basins Research Group (BRG),

Department of Earth Science and

Engineering, Imperial College London,

London, UK

${ }^{2}$ School of Earth and Environment, University of Leeds, Leeds, UK

${ }^{3}$ Department of Earth and

Environmental Sciences, University of

Manchester, Manchester, UK

\section{Correspondence}

Craig Magee, School of Earth and Environment, University of Leeds, Leeds, UK.

Email: c.magee@leeds.ac.uk

\section{Funding information}

Natural Environment Research

Council, Grant/Award Number: NE/

L501621/L

\begin{abstract}
Continental breakup involves a transition from rapid, fault-controlled syn-rift subsidence to relatively slow, post-breakup subsidence induced by lithospheric cooling. Yet the stratigraphic record of many rifted margins contain syn-breakup unconformities, indicating that episodes of uplift and erosion interrupt this transition. This uplift has been linked to mantle upwelling, depth-dependent extension and/or isostatic rebound. Deciphering the breakup processes recorded by these unconformities and their related rock record is challenging because upliftassociated erosion commonly removes the strata that help constrain the onset and duration of uplift. We examine three major breakup-related unconformities and the intervening rock record in the Lower Cretaceous succession of the Gascoyne and Cuvier margins, offshore NW Australia, using seismic reflection and borehole data. These data show the breakup unconformities are disconformable (non-erosive) in places and angular (erosive) in others. Our recalibration of palynomorph ages from rocks underlying and overlying the unconformities shows: (i) the lowermost unconformity developed between 134.98-133.74 Ma (Intra-Valanginian), probably during the localisation of magma intrusion within continental crust and consequent formation of continent-ocean transition zones (COTZ); (ii) the middle unconformity formed between ca. 134 and 133 Ma (Top Valanginian), possibly coincident with breakup of continental crust and generation of new magmatic (but not oceanic) crust within the COTZs; and (iii) the uppermost unconformity likely developed between ca. 132.5 and 131 Ma (i.e. Intra-Hauterivian), coincident with full continental lithospheric breakup and the onset of seafloor spreading. During unconformity development, uplift was focussed along the continental rift flanks, likely reflecting flexural bending of the crust and landward flow of lower crust and/or lithospheric mantle from beneath areas of localised extension towards the continent (i.e. depth-dependent extension). Our work supports the growing consensus that the breakup unconformity' is not always a single stratigraphic surface marking the onset of seafloor
\end{abstract}

This is an open access article under the terms of the Creative Commons Attribution License, which permits use, distribution and reproduction in any medium, provided the original work is properly cited.

(C) 2022 The Authors. Basin Research published by International Association of Sedimentologists and European Association of Geoscientists and Engineers and John Wiley \& Sons Ltd. 
spreading; multiple unconformities may form and reflect a complex history of uplift and subsidence during continent-ocean transition.

\section{K E Y W O R D S}

basin, breakup, palynology, rift, seismic reflection, unconformity, uplift

\section{1 | INTRODUCTION}

Continental breakup has traditionally been perceived to involve continuous subsidence of an evolving rifted margin, with initial fault-controlled, relatively rapid syn-rift subsidence followed by a protracted phase of relatively slow, post-rift subsidence induced by cooling of the lithosphere (e.g. Bott, 1982; Le Pichon \& Sibuet, 1981; McKenzie, 1978). However, the stratigraphic records of many passive margins contain one or more 'breakup unconformities' (Figure 1), which developed during the transition from continental rifting to seafloor spreading (e.g. Driscoll et al., 1995; Falvey, 1974; Franke, 2013; Gong et al., 2019; Lavin, 1997; Mohriak \& Leroy, 2013; Morley, 2016; Soares et al., 2012; Tucholke et al., 2007; Veevers, 1986; Xie et al., 2019). These breakup unconformities broadly separate faulted, syn-rift rocks from overlying, largely unfaulted post-rift rocks, indicating that subsidence was punctuated by a period (or periods) of uplift and/or erosion (e.g. Alves \& Cunha, 2018; Driscoll et al., 1995; Embry \& Dixon, 1990; Falvey, 1974; Pérez-Gussinyé et al., 2020). Such syn-breakup uplift has variously been attributed to: (i) a thermal response to mantle upwelling (e.g. Falvey, 1974; Morley, 2016); (ii) rift flank uplift caused either by convective heat transfer from deeper parts of a rifted basin (e.g. Cochran, 1983), or an isostatic response to depth-dependent extension (e.g. Issler et al., 1989; White \& McKenzie, 1988); or (iii) isostatic rebound of over-deepened sedimentary basins (e.g. Braun \& Beaumont, 1989). The magnitude and distribution of uplift is also influenced by lithospheric strength (see Pérez-Gussinyé et al., 2020 and references therein). The stratigraphic architecture and formation of these unconformities and their encasing strata, i.e. the breakup sequence, thus provide an important record of the tectonic and geodynamic evolution of continental margins (e.g. Alves \& Cunha, 2018; Gong et al., 2019; Monteleone et al., 2019; Pérez-Gussinyé et al., 2020; Peron-Pinvidic et al., 2019; Soares et al., 2012).

To understand the genesis and significance of breakuprelated unconformities, we must establish their distribution and structure, the depositional environments and subsidence history of a margin, and the timing of unconformity development relative to distinct tectonic and magmatic events (e.g. full lithospheric rupture and onset of

\section{Highlights}

- Unconformities developed during continental breakup are common on rifted margins.

- We constrain the distribution and age of three breakup unconformities offshore NW Australia.

- Unconformity development linked to discrete phases of extension localisation during breakup.

- Uplift focused along rift flanks and possibly driven by depth-dependent extension.

- Unlocking the stratigraphic record is key to unravelling geodynamics of continental breakup.

seafloor spreading). Most previous studies investigating the development and geodynamic significance of breakup unconformities are limited by: (i) seismic and borehole data quantity and quality (e.g. Soares et al., 2012); (ii) paucity of biostratigraphic constraints on the age of the breakup succession, particularly where erosion has removed rock beneath the breakup-related unconformities (e.g. Dafoe et al., 2017); (iii) poor dating of oceanic crust adjacent to the margin, which makes it difficult to establish whether unconformity development and onset of seafloor spreading were simultaneous (e.g. Cande \& Mutter, 1982); (iv) complications due to diachronous breakup along-strike and the formation of multiple breakup unconformities (e.g. Alves \& Cunha, 2018; Gillard et al., 2015; Larsen \& Saunders, 1998; Monteleone et al., 2019; Soares et al., 2012); or (v) the presence of substantial synbreakup igneous products, which tend to reduce the quality of seismic reflection data (e.g. Skogseid et al., 1992).

The North Carnarvon Basin, offshore NW Australia (Figure 2), is an ideal area to understand the syn-breakup stratigraphic record and thereby determine mechanisms of continental breakup. We use 2D and 3D reflection seismic surveys covering ca. $165,000 \mathrm{~km}^{2}$ and biostratigraphic data from 165 boreholes to better constrain the age and uplift distribution of three major unconformities that have previously dated to $138.2,134.9$ and ca. $132.5 \mathrm{Ma}$ (e.g. Arditto, 1993; Helby et al., 1987; Labutis, 1994; Paumard et al., 2018; Smith et al., 2015). Developing previous work, a recent examination of the nature and age of the Cuvier Abyssal 


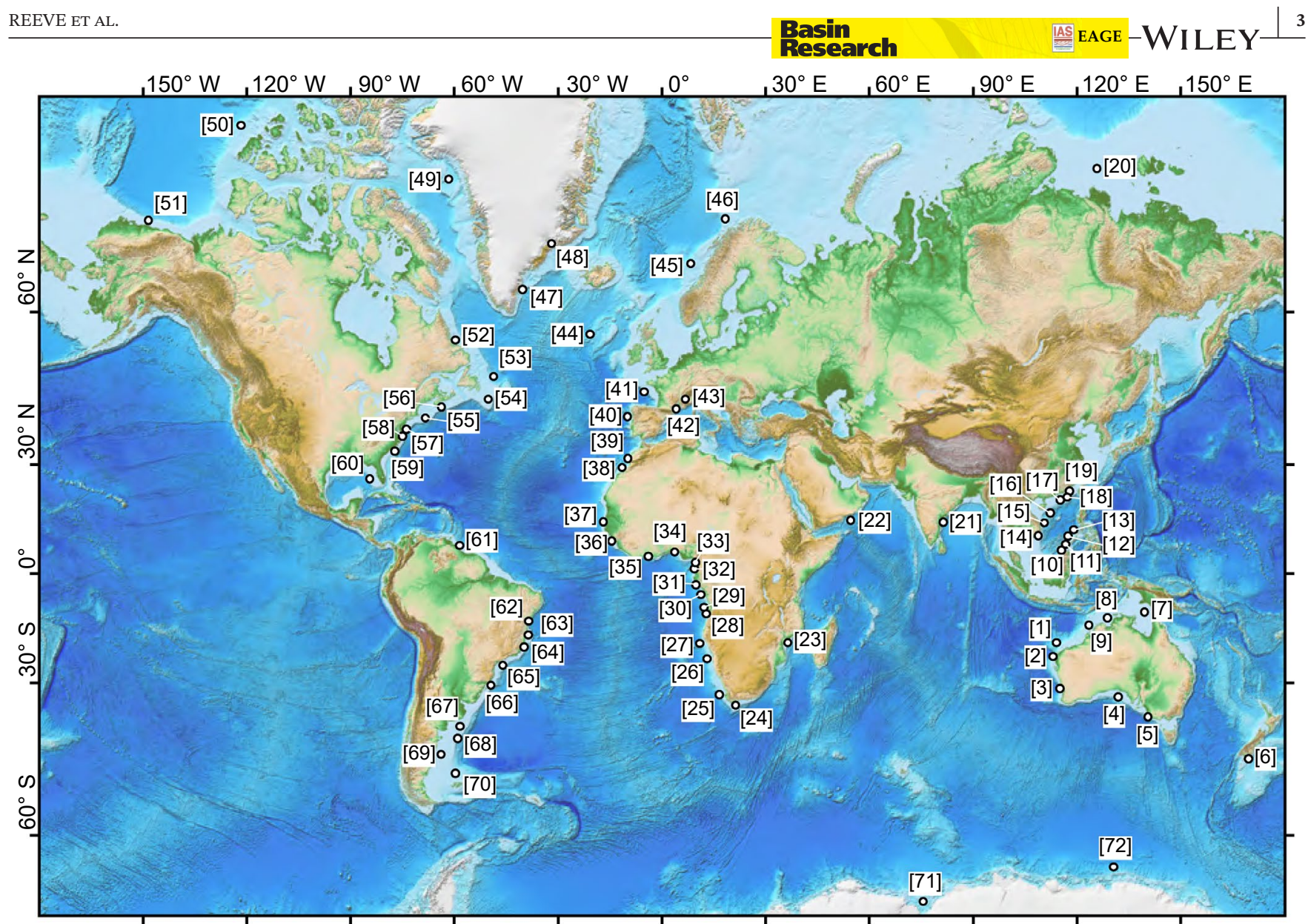

F I G U R E 1 Map showing global distribution of breakup unconformity locations from previous studies. Topography and bathymetry are from ETOPO1 Global Relief Model (Amante \& Eakins, 2009). For details of references used for each breakup unconformity location, see Table S1

Plain, adjacent to part of the North Carnarvon Basin, has shown continental breakup of NW Australia involved a period (ca. $6 \mathrm{Myr}$ ) of continent-ocean transition zone (COTZ) formation immediately before full lithospheric rupture occurred ca. $130 \mathrm{Ma}$ (Reeve et al., 2021). Although the three unconformities studied in this basin here have been broadly linked to continental breakup (e.g. Arditto, 1993; Helby et al., 1987; Labutis, 1994; Paumard et al., 2018; Smith et al., 2015), the tectonic processes driving their formation remain poorly understood. By recalibrating widely preserved dinoflagellate zones to align with sparsely recorded, yet temporally well-constrained occurrences of calcareous nannofossils, we show the three unconformities actually developed between 134.98 and $133.74 \mathrm{Ma}$, ca. 134 and $133 \mathrm{Ma}$ and ca. 132.5 and $131 \mathrm{Ma}$. By mapping the age, depositional environment and reworking of sedimentary rocks above and below the major breakup-related unconformities, we show that uplift was primarily focussed along rift flanks bordering continent-ocean transition zones (COTZs). We compare these constraints on unconformity development to the structure and magnetic stripe ages recorded in the neighbouring Early Cretaceous COTZs and oceanic crust. Based on these comparisons, we suggest that the three phases of uplift and unconformity development coincided with: (i) formation of narrow rift zones in the incipient COTZs, which involved and was at least partially driven by significant dyke intrusion into continental crust; (ii) a possible increase in dyke-driven, sub-aerial spreading; and (iii) the onset of lithospheric breakup and seafloor spreading. We speculate uplift and erosion were focussed along the rift flanks and occurred in response to loading of extrusive material at the rift axis driving flexural bending and the landward transfer of lower crustal and lithospheric mantle to beneath the rift flanks from areas of extension localisation. Overall, our work shows that the integration of seismic reflection and well-calibrated biostratigraphic data is critical to reading rocks that record the processes driving continental breakup.

\section{GEOLOGICAL SETTING}

The Palaeozoic-to-recent North Carnarvon Basin forms the southern-most part of Australia's Northwest Shelf, spanning 
the magma-rich Gascoyne and Cuvier margins (Figure 2) (e.g. Longley et al., 2002; Menzies et al., 2002; Symonds et al., 1998). The basin developed in response to multiple phases of rifting between the Late Carboniferous and Early Cretaceous, with internal sub-basins developing from the Late Triassic onwards (e.g. Longley et al., 2002; Stagg \& Colwell, 1994). In this study, we principally consider the Tithonian-to-Hauterivian phase of rifting that ultimately led to continental breakup between Australia and Greater India (Figure 3a) (e.g. Direen et al., 2008; Falvey \& Veevers, 1974; Heine \& Müller, 2005; Larson et al., 1979; Longley et al., 2002; Reeve et al., 2021; Robb et al., 2005; Stagg et al., 2004; Stagg \& Colwell, 1994; Willcox \& Exon, 1976).

\section{1 $\mid$ Margin sectors}

\subsection{1 | Gascoyne Margin}

The 450-700 km wide Gascoyne Margin contains a 100$250 \mathrm{~km}$ wide COTZ that hosts magnetic chrons M10NM5n (135.9-130.6 Ma), and is separated from the Cuvier Abyssal Plain to the south-west by the NW-trending Cape Range Fracture Zone (Figure 2a) (e.g. Direen et al., 2008). The oldest magnetic anomaly recorded in unambiguous oceanic crust adjacent to the Gascoyne Margin is chron M3n, which indicates full lithospheric rupture of the margin had occurred by ca. $130.6 \mathrm{Ma}$ (Hauterivian; Figures $2 \mathrm{~b}$ and 3a) (e.g. Direen et al., 2008; Robb et al., 2005).

Several tectonic elements are recognised within the Gascoyne Margin, including the Exmouth Plateau, and the Exmouth, Barrow, and Dampier sub-basins (Figure 2a). The Exmouth Plateau comprises thin $(<10 \mathrm{~km}$ thick $)$ crystalline crust overlain by a $\leq 18 \mathrm{~km}$-thick sedimentary sequence (e.g. Figure 3b) (Pryer et al., 2002; Stagg et al., 2004). Sedimentary successions in the Exmouth and Barrow sub-basins are ca. 10-18 km thick (e.g. Figure 3b), but locally up to ca. $24 \mathrm{~km}$ thick, making it difficult to seismically image the acoustic basement or Moho (e.g. Tindale et al., 1998). The lower portions of these sedimentary sequences are likely dominated by the Late Permian-to-Late Triassic, Locker Shale and Mungaroo Formation, which together are up to $9 \mathrm{~km}$ thick (Figure 3) (e.g. Hocking et al., 1987; Stagg \& Colwell, 1994). The Exmouth Plateau was sediment-starved during Late Triassic-to-Jurassic rifting, preserving only a condensed ( $\leq 100 \mathrm{~m}$ thick) stratigraphic record comprising clastic, shallow marine-to-deep marine, sedimentary strata of the Brigadier Formation, North Rankin Formation, Murat Siltstone, Athol Formation and Dingo Claystone (e.g. Boyd et al., 1993; Hocking, 1992). Up to $4 \mathrm{~km}$ of Late Triassic-to-Jurassic strata accumulated in the Exmouth and Barrow sub-basins (Figure 3) (e.g. Stagg \& Colwell, 1994). Tithonian-to-Valanginian rifting of the
Gascoyne Margin provided accommodation for a $\leq 3.5 \mathrm{~km}$ thick sequence of clastic deltaic rocks of the Barrow Group (Figure 3) (e.g. Paumard et al., 2018; Reeve et al., 2016). A series of arches, which correspond to areas of localised uplift and erosion, occur across the Gascoyne Margin (Figure 2) (e.g. Tindale et al., 1998): (i) the Alpha Arch likely formed in the Triassic-to-Jurassic in response to rift-related faulting and separates the Exmouth and Barrow Sub-basins; (ii) the Ningaloo Arch, erosion of which may have provided the source material for the Zeepaard Formation, is suggested to have formed during the Valanginian due to inversion driven by seafloor spreading in the Cuvier Abyssal Plain; and (iii) the Novara, Resolution and Exmouth Plateau arches, which formed during post-breakup inversion events between the Santonian and present day.

\subsection{2 | Cuvier Margin}

The 100-200 km wide Cuvier Margin has previously been interpreted to include a ca. $50 \mathrm{~km}$ wide COTZ, which borders the Cuvier Abyssal Plain to the NW (e.g. Figure 2a) (Colwell et al., 1994; Hopper et al., 1992; Longley et al., 2002; Stagg et al., 2004). Proximal areas of the Cuvier Margin include the southern part of the Exmouth Sub-basin, which has been termed the Carnarvon Terrace (Figure 2a) (e.g. Mihut \& Müller, 1998; Müller et al., 2002). The continental crust beneath the Carnarvon Terrace and South Carnarvon Basin is estimated to be ca. 25-30 km thick (Hopper et al., 1992). Although the stratigraphy of the offshore Cuvier Margin is poorly constrained due to limited borehole data, it is likely similar to that of the northern part of the Exmouth Sub-basin (Figure 3a) (e.g. McClay et al., 2013; Partington et al., 2003). During Tithonian-to-Hauterivian rifting, uplift and erosion of the onshore South Carnarvon Basin, perhaps driven by depth-dependent extension or dynamic topography, provided material for the Barrow Group to the north (Paumard et al., 2018; Reeve et al., 2016).

Recognition of magnetic chrons M10N-M5n within assumed oceanic crust of the Cuvier Abyssal Plain has been used to suggest that breakup and lithospheric rupture of the Cuvier Margin had occurred by ca. $136 \mathrm{Ma}$ (Valanginian; Figures 2b and 3a) (Falvey \& Veevers, 1974; Larson et al., 1979); this model implies breakup of the Cuvier Margin occurred ca. 5 Myr before breakup of the Gascoyne Margin (Reeve et al., 2021). However, Reeve et al. (2021) have recently recognised seaward-dipping reflector (SDR) sequences, which likely correspond to stacked lava flows, across the Cuvier Abyssal Plain. Based on sedimentological, biostratigraphic and geochemical data, Reeve et al. (2021) infer these lava sequences were extruded within subaerialto-shallow marine conditions and their parental magmas may have been contaminated by continental material. 
(a)

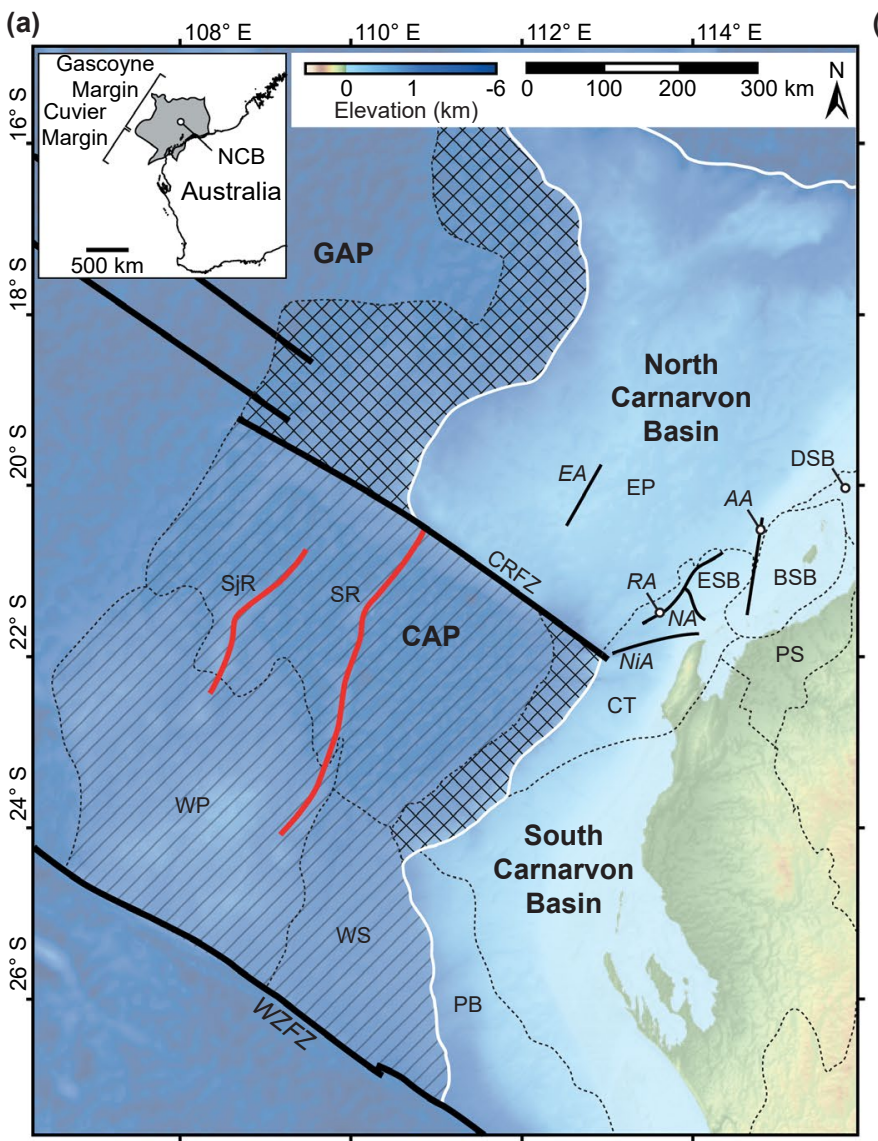

(b)

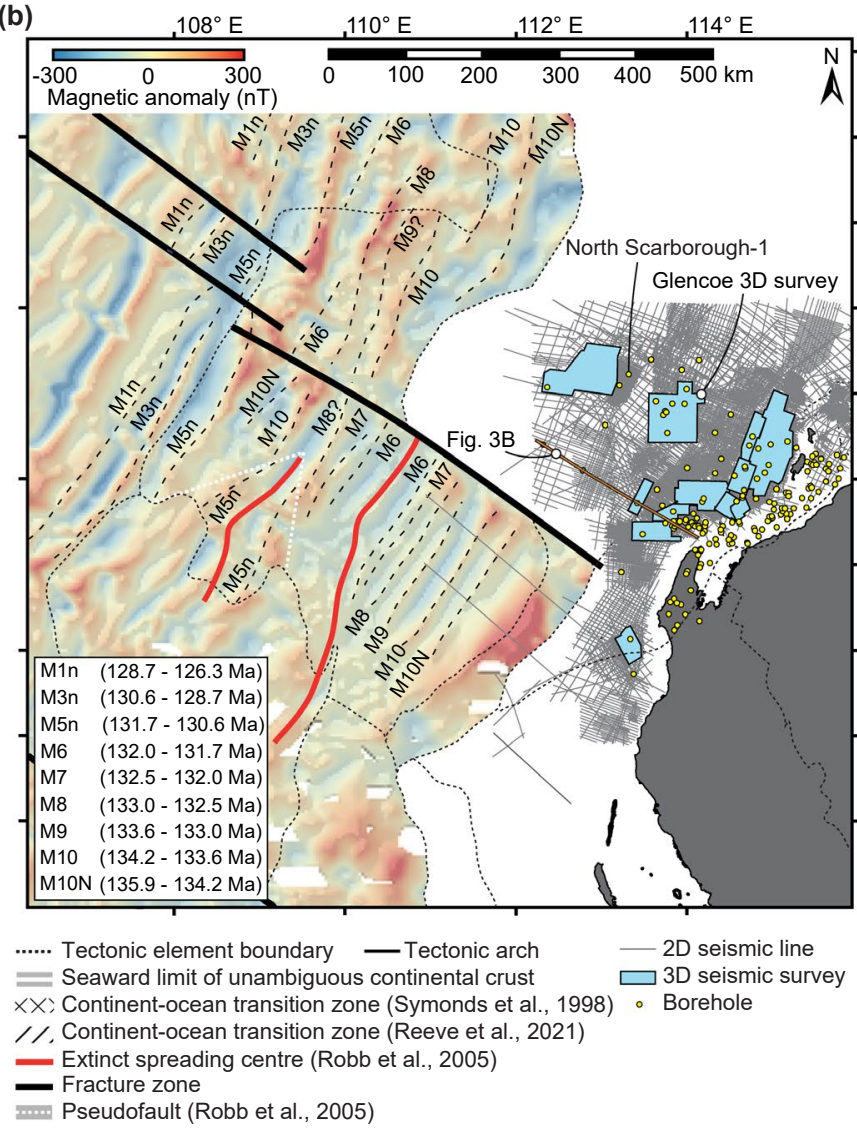

F I G U RE 2 (a) Map of the North and South Carnarvon basins highlighting principal tectonic elements, including: BSB, Barrow subbasin; CAP, Cuvier Abyssal Plain; CRFZ, Cape Range Fracture Zone; CT, Carnarvon Terrace; DSB, Dampier sub-basin; EP, Exmouth Plateau; ESB, Exmouth Sub-basin; GAP, Gascoyne Abyssal Plain; PB, Perth Basin; PS, Peedamullah Shelf; SjR, Sonja Ridge; SR, Sonne Ridge; WP, Wallaby Plateau; WS, Wallaby Saddle; WZFZ, Wallaby-Zenith Fracture Zone. The location of the Resolution Arch (RA), Exmouth Plateau $\operatorname{Arch}(E A)$, Alpha Arch $(A A)$, Novara Arch $(N A)$, and Ningaloo Arch $(N i A)$ are also shown. Elevation data are based on the 2009 Australian Bathymetry and Topography grid (Geoscience Australia). Inset: Location map of the North Carnarvon Basin (NCB) relative to Australia and the Gascoyne and Cuvier margins. (b) Map showing extent of 2D and 3D seismic reflection data coverage and locations of boreholes used in this study. Total magnetic intensity grid (EMAG2v2) also shown with interpreted magnetic chrons (based on Robb et al., 2005)

These constraints on lava emplacement and genesis suggest the Cuvier Abyssal Plain may actually be part of the Cuvier COTZ, as opposed to fully oceanic crust (Figure 2) (Reeve et al., 2021). If the Cuvier Abyssal Plain is part of a COTZ, the oldest magnetic anomaly recorded in adjacent unambiguous oceanic crust (i.e. chron M3n) would imply full breakup of the Cuvier Margin occurred simultaneous to breakup along the Gascoyne Margin before ca. 130.6 Ma (Hauterivian) (Figures 2b and 3a) (e.g. Direen et al., 2008; Reeve et al., 2021).

\section{2 | Breakup-related unconformitiesand bounding strata}

Three major unconformities are recognised in the North Carnarvon Basin that, based on their age, have been broadly linked to continental breakup (Figure 3) (e.g. Arditto, 1993; Reeve et al., 2016; Romine \& Durrant, 1996): the Intra-Valanginian unconformity (IVU); the Top Valanginian unconformity (TVU) and the IntraHauterivian unconformity (IHU).

\subsection{1 | Intra-Valanginian unconformity}

Previous terms for the IVU include the: Valanginian unconformity (e.g. McClay et al., 2013; Tindale et al., 1998); Intra-Valanginian sequence boundary (e.g. Romine \& Durrant, 1996); KV seismic event or unconformity (e.g. Longley et al., 2002; Paumard et al., 2018); K-SAS5 sequence boundary (e.g. Jablonski, 1997); K20.0 sequence boundary (e.g. Marshall \& Lang, 2013; Smith et al., 2015); Base Cretaceous unconformity (e.g. Baillie \& Jacobson, 

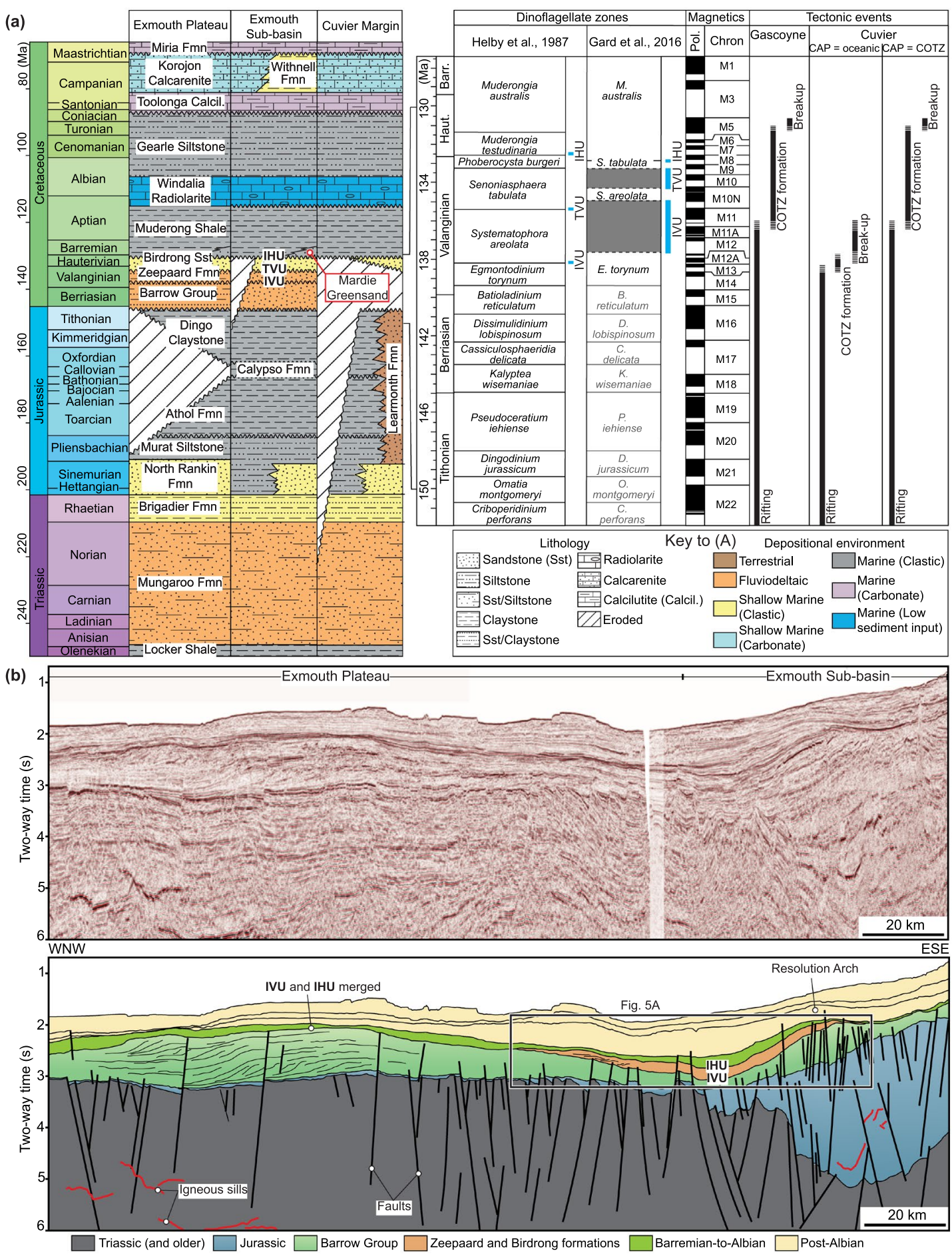

F I G U RE 3 (a) Stratigraphic column for the Exmouth Plateau, Exmouth Sub-basin and Cuvier Margin summarising the age, dominant lithology and generalised depositional environment for key units (after Arditto, 1993; Hocking, 1992; Hocking et al., 1987; Partington et al., 2003). Dinoflagellate zone schemes from Helby et al. (1987) and Gard et al. (2016) highlighting their implications for unconformity timing; grey areas encompass the possible age of respective dinoflagellate zone boundaries. Numerical ages and geomagnetic polarity also shown (Cohen et al., 2013, updated; Gradstein et al., 2012). IHU, Intra-Hauterivian Unconformity; IVU, Intra-Valanginian unconformity; TVU, Top-Valanginian unconformity. Key tectonics events shown for comparison: two scenarios for the Cuvier Abyssal Plain (CAP) are included where it is either oceanic crust of a continent-ocean transition zone (COTZ) (see Reeve et al., 2021 and references therein). (b) Uninterpreted and interpreted seismic section, showing generalised stratigraphic architecture of the Exmouth Plateau and Exmouth Subbasin. See Figure $2 \mathrm{~b}$ for location and Figure 3a for key 
1995; Müller et al., 2002); and breakup unconformity (e.g. Romine \& Durrant, 1996). The IVU commonly marks the top of the Barrow Group and has been inferred to coincide with the boundary between the Egmontodinium torynum and Systematophora areolata dinoflagellate zones (Figure 3a) (Arditto, 1993; Labutis, 1994; Paumard et al., 2018; Smith et al., 2015). This E. torynum and S. areolata dinoflagellate zone boundary was originally interpreted to occur at 138.2 Ma, which most studies adopt as the age of what we here refer to as the IVU (Figure 3a) (e.g. Arditto, 1993; Helby et al., 1987; Labutis, 1994; Paumard et al., 2018; Smith et al., 2015). However, recent recalibration of these zones using biostratigraphic data from the North Scarborough-1 borehole suggests this boundary, and thus the IVU, could have formed later, between 137.55 and 134.98 Ma (Figure 3a) (Gard et al., 2016).

Many studies relate the IVU to Early Cretaceous breakup of Australia and Greater India, and have linked the associated uplift driving its formation to: (i) a prebreakup thermal event, perhaps related to the impingement of a mantle plume at the base of the crust (e.g. Black et al., 2017; Rohrman, 2015), suggesting the IVU formed before lithospheric rupture and the onset of seafloor spreading (Figure 3a); (ii) small-scale mantle convection driven by the juxtaposition of thin and thick lithosphere across the ca. 136 Myr old Cape Range Fracture Zone, suggesting the IVU formed before or during lithospheric rupture and the onset of seafloor spreading (e.g. Müller et al., 2002; Reeve et al., 2021); (iii) thermal uplift driven by the onset of oceanic crust formation to the north-west, suggesting the IVU formed during lithospheric rupture and seafloor spreading (cf. Figure 3a) (e.g. Romine \& Durrant, 1996; Stagg \& Colwell, 1994); (iv) inversion and formation of the Ningaloo Arch, driven by ridge-push forces, suggesting the IVU formed after the onset of seafloor spreading (e.g. Paumard et al., 2018; Tindale et al., 1998); or (v) a major eustatic sea level fall and associated period of nondeposition, i.e. the formation of the IVU was not tectonically controlled (e.g. Jablonski, 1997).

\subsubsection{Top Valanginian unconformity}

The TVU has been interpreted to coincide with the boundary between the $S$. areolata and Senoniasphaera tabulata dinoflagellate zones (Figure 3a) (Arditto, 1993; Helby et al., 1987). This dinoflagellate zone boundary was originally considered to occur at $134.9 \mathrm{Ma}$, but recalibration of the North Scarborough-1 biostratigraphic data suggest it may be slightly younger (134.32-133.29 Ma; Figures $2 \mathrm{~b}$ and 3a) (Gard et al., 2016). The TVU is locally recognised in the Exmouth and Barrow sub-basins and marks the top of the Zeepaard Formation, a relatively thin $(<300 \mathrm{~m}$ thick), progradational deltaic sequence (Figure 3a) (e.g. Arditto, 1993; Paumard et al., 2018; Reeve et al., 2021). This unit has also been defined as the Upper Barrow Group (Paumard et al., 2018), but because it formed after the IVU in response to different uplift and subsidence processes relative to the Barrow Group sensu stricto, we refer to it as the Zeepaard Formation. The overlying ca. 20-30 m thick Birdrong Sandstone Formation is sandstone-dominated, with minor siltstone and conglomerate, and was deposited in a shoreface environment (Thompson et al., 1990). The presence of the TVU between these units suggests a period of minor uplift may have separated deposition of the Zeepard Formation and Birdrong Sandstone, although the processes driving this have not been previously considered.

\subsubsection{Intra-Hauterivian unconformity}

The youngest breakup-related unconformity in the North Carnarvon Basin, the IHU, has been interpreted to coincide with the proposed ca. 132.5 Myr old boundary between the Phoberocysta burgeri and Muderongia testudinaria dinoflagellate zones (Figure 3a) (Arditto, 1993; Helby et al., 1987); the $P$. burgeri and $M$. testudinaria zones are missing or not sampled in the North Scarborough-1 borehole analysed by Gard et al. (2016). The IHU defines the top of the shallow marine Birdrong Sandstone, and the base of the overlying Mardie Greensand Member or Muderong Shale Formation (Figure 3a) (e.g. Arditto, 1993). The Mardie Greensand Member is predominantly composed of highly glauconitic sandstone, deposited in a shelfal marine environment; this unit passes laterally and vertically into the marine Muderong Shale Formation (Thompson et al., 1990).

\section{3 | DATASET AND METHODOLOGY}

\section{1 | Data}

We analyse a ca. $165,000 \mathrm{~km}^{2}$ grid of publicly available 2D seismic data and 12 3D reflection seismic datasets (Figure 2b; see also Table S2). Two-dimensional seismic line spacing ranges from ca. 0.5 to $10 \mathrm{~km}$, but is typically $<5 \mathrm{~km}$. Vertical record length ranges from 3.5 to $16 \mathrm{~s}$ two-way travel-time (TWT). We use publicly available commercial palynology and micropalaeontology reports from 165 onshore and offshore boreholes to constrain stratigraphic ages above and below the breakup-related unconformities, and to investigate the abundance, timing and distribution of sedimentary reworking related to margin uplift and erosion (Figure $2 \mathrm{~b}$; see also Table $\mathrm{S} 3$ ). 


\subsection{Unconformity mapping}

We use checkshot data and borehole logs to tie well and seismic reflection data, allowing us to identify and map the IVU and IHU regionally within the 2D and 3D seismic reflection datasets. Where these unconformities were difficult to identify in seismic reflection data, or these data were unavailable, we use boreholes to constrain their stratigraphic context and extent. We do not regionally map the TVU within the seismic reflection data because its corresponding reflection is laterally discontinuous, making it difficult to confidently interpret; we instead define the position of the TVU using borehole data.

By using the mapped IVU and IHU horizons, we calculated the intervening stratal thickness of the Zeepaard Formation and Birdrong Sandstone to construct an isochore map. Because the Birdrong Sandstone is consistently 20-30 m thick (Thompson et al., 1990), we use this isochore map to primarily identify major thickness changes in the substantially thicker Zeepaard Formation, allowing us to: (i) locate syn-depositional regions of relatively high and low accommodation, which potentially relate to areas of subsidence and uplift, respectively; and (ii) identify where uplift during the development of the TVU or IHU may have led to the erosion of the Zeepaard Formation.

\subsection{Calibration of dinoflagellate and calcareous nannofossil zones}

Constraining the exact timing and duration of unconformity generation is often complicated by erosion of stratigraphy at the unconformable contact, which commonly represents a significant time gap (e.g. Miall, 2016). Without confidence in age estimates for the unconformities, it is difficult to relate their formation to distinct tectonic and/or magmatic processes (e.g. Huang et al., 2017). The unconformities studied here have previously been correlated to dinoflagellate zone boundaries, but ages attributed to these palynological zonation schemes are poorly calibrated to the global chronostratigraphic timeframe (Figure 3a) (e.g. Arditto, 1993; Gard et al., 2016; Helby et al., 1987). To help constrain the age of unconformity formation we adopt a methodology similar to Gard et al. (2016), and use biostratigraphic data collected every $5 \mathrm{~m}$ from the Lightfinger- 1 and Nimblefoot- 1 boreholes to revise the timing of the $S$. areolata to M. testudinaria dinoflagellate zones. We use these boreholes because they intersect relatively complete successions of Early Cretaceous strata that preserve both dinoflagellate cysts and calcareous nannofossils, the global first and last occurrences of which are well-calibrated to the global chronostratigraphic timeframe (e.g. Gard et al., 2016). These well-calibrated calcareous nannofossil ages allow us to tie dinoflagellate zone boundaries to global chronostratigraphy (Gard et al., 2016).

\subsection{Unconformity subcrop and supercrop ages}

We perform a joint analysis of seismic reflection and borehole data to constrain the ages of the sedimentary section directly above and below the breakup-related unconformities. Specifically, we use revised dinoflagellate zones to assign ages to the strata underlying (subcrop) and overlying (supercrop) the oldest breakup unconformity identifiable at each borehole location. For example, where all three breakup-related unconformities (i.e. IVU, TVU, and IHU) are present, we record the age of strata directly above and below the IVU. Where the IVU and TVU are eroded by the IHU (i.e. only the IHU is present), we record the age of strata directly above and below the IHU. Due to limitations in data availability, we focus on the oldest unconformities at each location because subcrop data for these allow us to reconstruct areas of relative uplift (or net-zero subsidence) and related erosion. Our interpreted palynology results for unconformity subcrop and supercrop ages at each well are included in Table S2.

\subsubsection{Reworking of palynomorphs}

We investigate geographical changes in sediment source, which can help identify areas of uplift during IVU formation, by examining the reworking of early Valanginian (and earlier) palynomorphs in the Zeepaard Formation (see Reeve et al., 2016). For boreholes where reworking is not explicitly described in the palynology report, we utilise species occurrence charts, in addition to the stratigraphic age range for each species documented by Helby et al. (1987), to assess whether older, reworked palynomorphs are present and, if so, their abundance.

\section{4 | RESULTS}

\section{1 | Distribution and structure of breakup-related unconformities}

We recognise the IVU and IHU across most of the Gascoyne Margin, and note the IHU extends south onto the Cuvier Margin (Figure 4). Across the northern sector of our study area, the IVU is broadly a disconformity (purple colour in Figure 4c), i.e. strata above and below are sub-parallel 

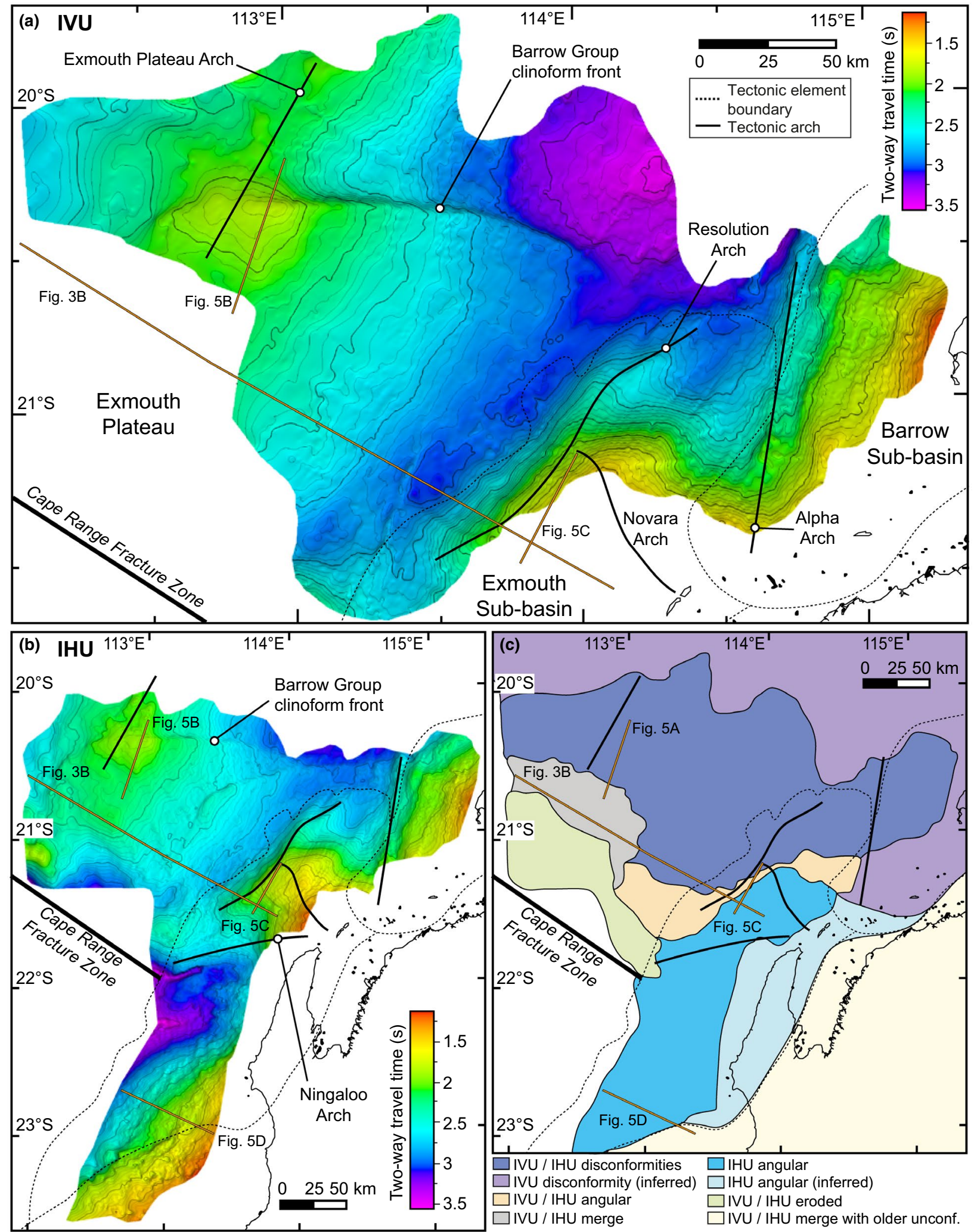

F I G U RE 4 (a) Two-way time structure map of the Intra-Valanginian Unconformity (IVU) seismic horizon. (b) Two-way time structure map of the Intra-Hauterivian Unconformity (IHU) seismic horizon. (c) Map showing the interpreted structural configuration of the Intra-

Valanginian and Intra-Hauterivian unconformities

to its surface, but there is an age gap between them (e.g. Figure 5a,b). In some places, underlying reflections are truncated by and overlying reflections onlap onto the IVU, particularly where it marks the arcuate, E-W trending clinoform front of the Barrow Group (e.g. Figures 4a and 5a,b). We also map a narrow ( $<50 \mathrm{~km}$ wide), E-trending zone 

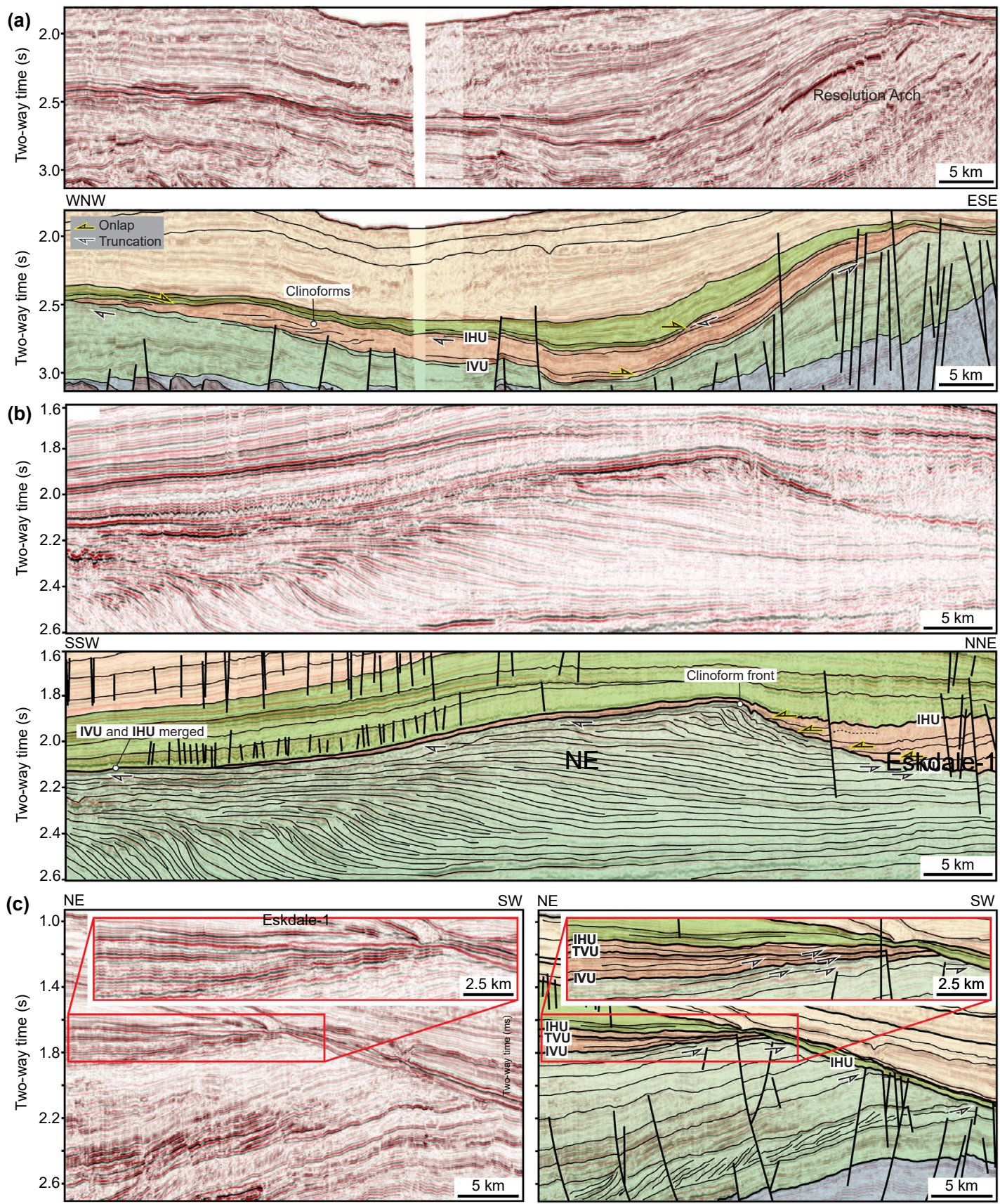

(d)

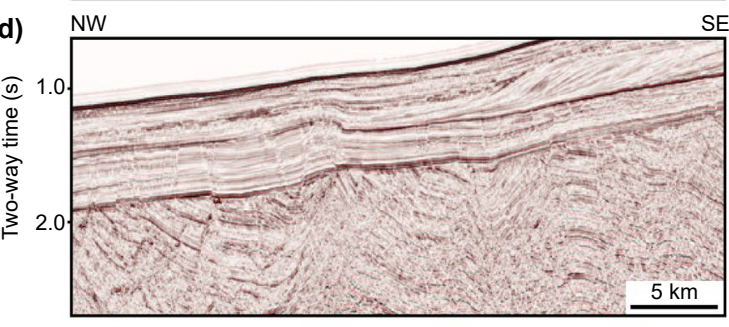

SE NW

SE

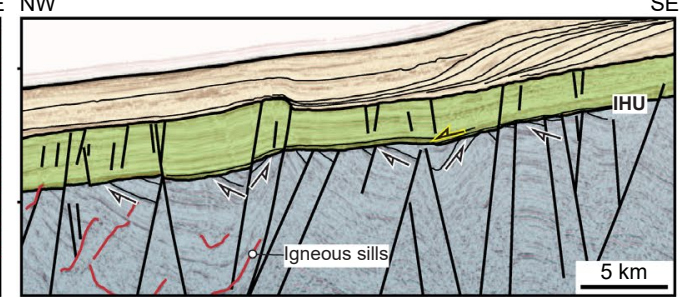

Triassic (and older) $\square$ Jurassic $\square$ Barrow Group $\square$ Zeepaard and Birdrong formations $\square$ Barremian-to-Albian $\square$ Post-Albian

F I G U RE 5 (a) Uninterpreted and interpreted zoomed-in seismic section focussing on the IVU and IHU. See Figure 4 for location and Figure 3b for key. (b) Uninterpreted and interpreted seismic section from the southern Exmouth Plateau, showing the relationship of the IVU and IHU to the Barrow Group and overlying stratigraphy. See Figure 4 for location and Figure $3 b$ for key. (c) Uninterpreted and interpreted seismic section from the Novara Arch area, showing the relationship between Early Cretaceous unconformities and breakuprelated compressional structures See Figure 4 for location and Figure $3 b$ for key. (d) Uninterpreted and interpreted seismic section from the Carnarvon Terrace showing the structural style of the Intra-Hauterivian Unconformity and underlying stratigraphy. See Figure 4 for location and Figure $3 \mathrm{~b}$ for key 
along the southern extent of the IVU, across part of the Resolution Arch, where the truncation of underlying reflections is common; i.e. here the IVU becomes an angular unconformity (e.g. Figures $4 \mathrm{c}$ and $5 \mathrm{c}$ ). Across these areas, the form of the TVU and IHU mirror the disconformable or angular nature of the underlying IVU (e.g. Figures $4 \mathrm{c}$ and $5 \mathrm{a}-\mathrm{c}$ ). In the south of the Exmouth Plateau, the IVU and IHU appear to merge (e.g. grey colour in Figure 4c), but adjacent to the Cape Range Fracture Zone these unconformities are themselves eroded by younger, post-breakup unconformities (green colour in Figure 4c). Across the southern portion of the Exmouth Sub-basin, including over the Novara and Ningaloo arches, and Carnarvon Terrace the IHU defines a prominent angular unconformity, eroding into and forming a composite surface with the IVU and TVU (blue colour in Figures $4 \mathrm{c}$ and $5 \mathrm{~d}$ ).

\subsection{Constraints on the age of Early Cretaceous unconformities}

Here we describe the calcareous nannofossil and dinoflagellate occurrences within the strata bounding the breakup unconformities where they are intersected by the Lightfinger-1 and Nimblefoot-1 boreholes (Figure 6). Using this information we later (Section 5.1) recalibrate the ages of dinoflagellate zone boundaries that have previously been used to define the ages of the IVU, TVU and IHU (e.g. Arditto, 1993; Helby et al., 1987).

The lowermost calcareous nannofossils in Lightfinger-1 and Nimblefoot- 1 that can help constrain the ages of the break-up unconformities are the first occurrences of Eiffelithus striatus (Figure 6). In Lightfinger-1, E. striatus is first found at ca. $2655 \mathrm{~m}$ depth, within the $S$. areolata dinoflagellate zone and above the IVU, whereas in Nimblefoot-1 the first occurrence of E. striatus is found at ca. $2640 \mathrm{~m}$ depth within the E. torynum zone and below the IVU (Figure 6). In Lightfinger-1, the last occurrence of Eiffelithus windii comprises a single nannofossil found at ca. $2610 \mathrm{~m}$ depth, above the IVU and immediately below the TVU (Figure 6). Between the IVU and TVU in Nimblefoot-1, in the $S$. areolata dinoflagellate zone, the shallowest occurrences of Cruciellipsis cuvillieri (2630 m) and Speetonia colligata (2625 m) are recorded (Figure 6).

There are no recorded samples from the $S$. tabulata dinoflagellate zone in either borehole (Figure 6), which is expected to occur above the TVU (e.g. Arditto, 1993; Helby et al., 1987). However, we note the first Zeugrhabdotus scutula and last $E$. striatus calcareous nannofossils are found directly above the TVU in Nimblefoot- 1 at ca. $2615 \mathrm{~m}$ depth (Figure 6). In contrast to Nimblefoot-1, there is an overlap in Lightfinger-1 between the occurrence of $Z$. scutula (ca. 2560-2540 m depth) and the last occurrence of E. striatus (ca. $2540 \mathrm{~m}$ depth), which was found alongside a single specimen of Lithraphidites bolli, within the M. testudinaria dinoflagellate zone above the IHU (Figure 6). The shallowest samples from the $M$. testudinaria dinoflagellate zone in Lightfinger-1 occur at ca. 2525-2530 m and also contain the shallowest occurrence of $C$. cuvillieri (Figure 6).

\section{3 | Breakup-related sedimentary deposits}

To investigate the distribution of uplift and the sedimentary response to tectonic events during breakup, here we describe results from our analysis of the stratigraphic architecture and palynology of the Zeepaard Formation.

\subsection{1 | Unconformity subcrop}

Tithonian-to-Valanginian strata of the Barrow Group occur directly below the IVU, or the IHU where it has eroded the IVU; the exception to this is adjacent to the Australian coast where the subcropping rocks are Carboniferous-toUpper Jurassic (Figures 3, 5a-c, and 7a). The subcropping Barrow Group rocks typically belong to the E. torynum dinoflagellate zone, although in places over the Alpha Arch and particularly towards the coast they are of the older, Batioladinium reticulatum or Dissimulidinium lobispinosum dinoflagellate zones (Figure 7a). Beneath the IHU, where it forms an angular unconformity, Barrow Group rocks belonging to the Pseudoceratium iehiense dinoflagellate zone occur along an E-trending transect, across the Novara Arch (Figure 7a). Further south, along the Cape Range Anticline and in two locations within the offshore Carnarvon Terrace, subcrop ages beneath the angular IHU range from Carboniferous-to-Upper Jurassic (Figure 7a).

\subsection{2 | Unconformity supercrop strata}

The Valanginian Zeepaard Formation, or its mudstonedominated distal equivalent, typically overlies the IVU and corresponds to the $S$. areolata dinoflagellate zone (Figures 3, 5a-c, and 7b). Across parts of the Alpha Arch and particularly proximal to the Australian coast, the IVU is overlain by the Birdrong Sandstone Formation (S. tabulatato-P. burgeri) or Mardie Greensand (S. tabulata-to-M. testudinaria), comprising rocks that are younger than the Zeepaard Formation (Figure 7b). The Birdrong Sandstone Formation and Mardie Greensand, as well as the Muderong Shale, also directly overlie the IHU where it has eroded the IVU and TVU (Figure 7b). These supercropping rocks are typically attributable to the $M$. australis or O. operculata dinoflagellate zones (Figure 7b). 


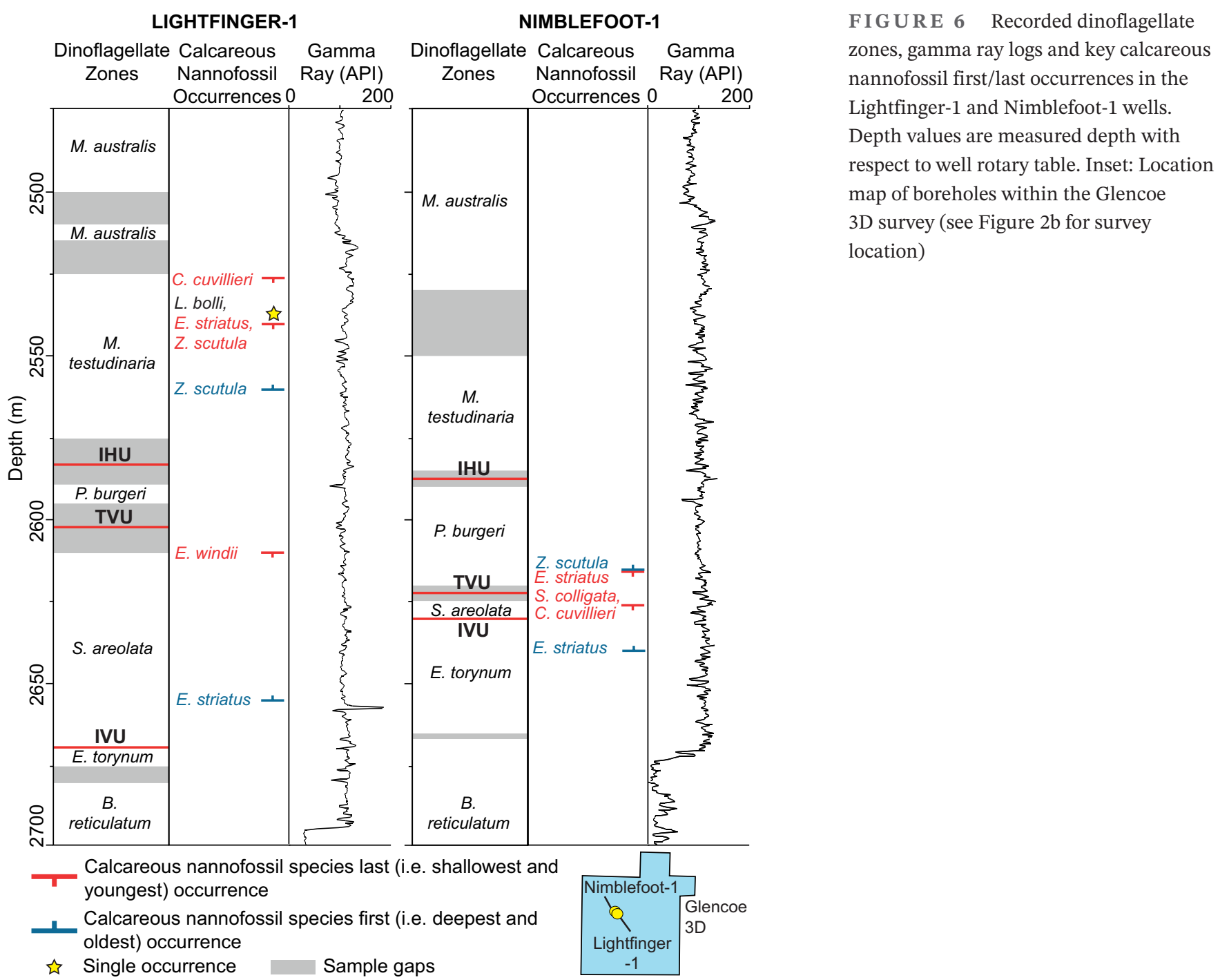

\subsection{3 $\quad$ Distribution and thickness of the Zeepaard Formation}

The main depocentre of the Zeepaard Formation, where it is up to ca. $300 \mathrm{~ms}$ TWT thick, lies on the north-western flank of the Resolution Arch (Figure 8a). From this main depocentre, the Zeepaard Formation thins westwards to ca. $25 \mathrm{~ms}$ TWT thick across its associated clinoform front, and eastwards to a 75-150 ms TWT thickness in the Barrow Sub-basin (Figure 8a). North of the Barrow Group clinoform front, the distal equivalent of the Zeepaard Formation thickens to ca. 150-200 ms TWT (Figure 8a). The Zeepaard Formation is absent across most of the Novara Arch and areas further south (Figure 8a).

\subsection{4 | Palynology of the Zeepaard Formation}

The Zeepaard Formation contains reworked Cretaceous, Jurassic, Triassic and Permian palynomorphs (Figure 8b).
In some of its distal areas, adjacent to its clinoform front, the Zeepaard Formation contains only reworked Jurassic and Cretaceous palynomorphs (e.g. Spar-1, East Spar1; Figure 8b). North of its clinoform front, the Zeepaard Formation does not contain reworked palynomorphs (e.g. Mentorc-1, Satyr-1; Figure 8b). Carboniferous or older reworking is scarce and only recorded in the York-1 and Woollybutt-3A boreholes (Figure 8b). We do not observe evidence of palynomorph reworking in several wells on the Alpha Arch (i.e. Minden-1, Johnson-1, Bowers-1 and Nimrod-1; Figure 8b).

\section{DISCUSSION}

\section{1 | Timing of unconformity development and relationships to tectonic events}

To help correlate unconformity development to discrete breakup-related events and processes, we recalibrate the 
FI G URE 7 (a) Map showing the youngest recorded stratigraphic ages beneath the breakup unconformity (subcrop) in wells from the onshore and offshore North and South Carnarvon Basins, based on palynology reports. The location of the Resolution Arch $(R A)$, Exmouth Plateau Arch (EA), Alpha Arch $(A A)$, Novara Arch $(N A)$ and Ningaloo Arch (NiA) are also shown. (b) Map showing the oldest recorded dinoflagellate zones and formation above the breakup unconformity (supercrop) in wells from the onshore and offshore North and South Carnarvon Basins, based on palynology reports
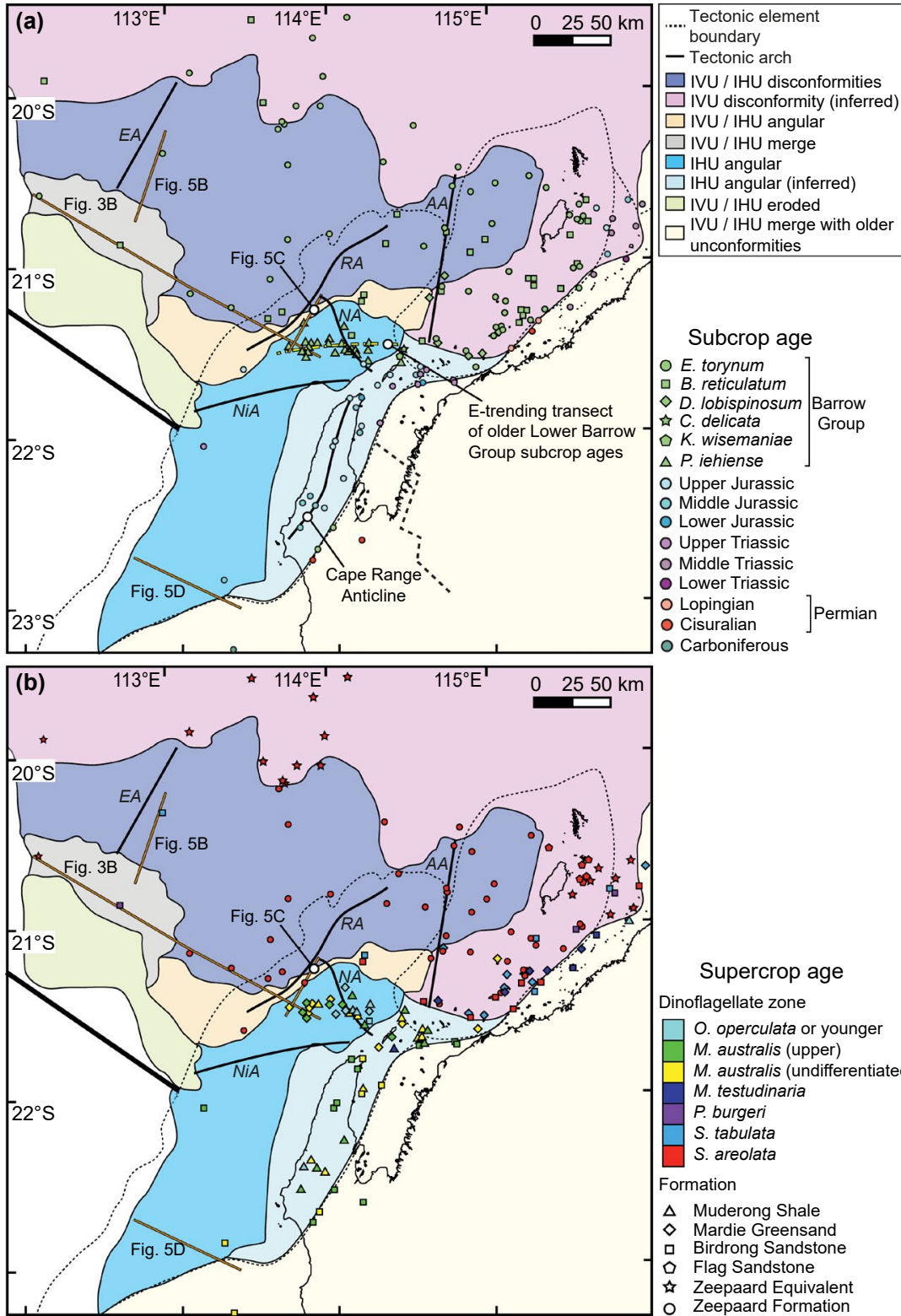

Supercrop age Dinoflagellate zone O. operculata or younger M. australis (upper) $M$. australis (undifferentiated) M. testudinaria

P. burgeri

S. tabulata S. areolata Formation

$\Delta$ Muderong Shale Mardie Greensand Birdrong Sandstone Flag Sandstone Zeepaard Equivalent Zeepaard Formation local dinoflagellate palynomorph record that has previously been used to constrain the age of the IVU, TVU and IHU (e.g. Arditto, 1993; Helby et al., 1987). Specifically, we tie palynomorph distribution to occurrences of calcareous nannofossils, which have globally robust age assignations (Gard et al., 2016). Here, we discuss how our recalibrated unconformity ages inform the breakup history of the Gascoyne and Cuvier margins.

\subsection{1 | IVU age and geodynamic significance}

The IVU corresponds to the boundary between the $E$. torynum and $S$. areolata dinoflagellate zones, and has previously been interpreted to have formed in the Early Valanginian (138.2 Ma) during continental breakup and seafloor spreading (Figure 3a) (e.g. Arditto, 1993; Helby et al., 1987; Paumard et al., 2018; Romine \& Durrant, 1996). We show that strata below the IVU in Nimblefoot-1 contain E. striatus calcareous nannofossils (Figure 6), which globally first appeared at $134.98 \mathrm{Ma}$ and disappeared at $132.89 \mathrm{Ma}$ (Gard et al., 2016); i.e. the IVU formed after $134.98 \mathrm{Ma}$. We note that the E. striatus nannofossils in Lightfinger-1 only occur above the IVU, in contrast to Nimblefoot-1 (Figure 6), implying these do not record the global first occurrence of this species. The presence of these calcareous nannofossils thus indicate their host sedimentary rocks, located above and below the IVU, were deposited between 134.98 and $132.89 \mathrm{Ma}$ (cf. Helby et al., 1987). Our borehole data also reveal the last occurrence of $E$. windii within Lightfinger-1 is ca. $60 \mathrm{~m}$ above the IVU, which indicates the unconformity formed, and at least part of the overlying Zeepaard Formation had been deposited, before the last global appearance of this 

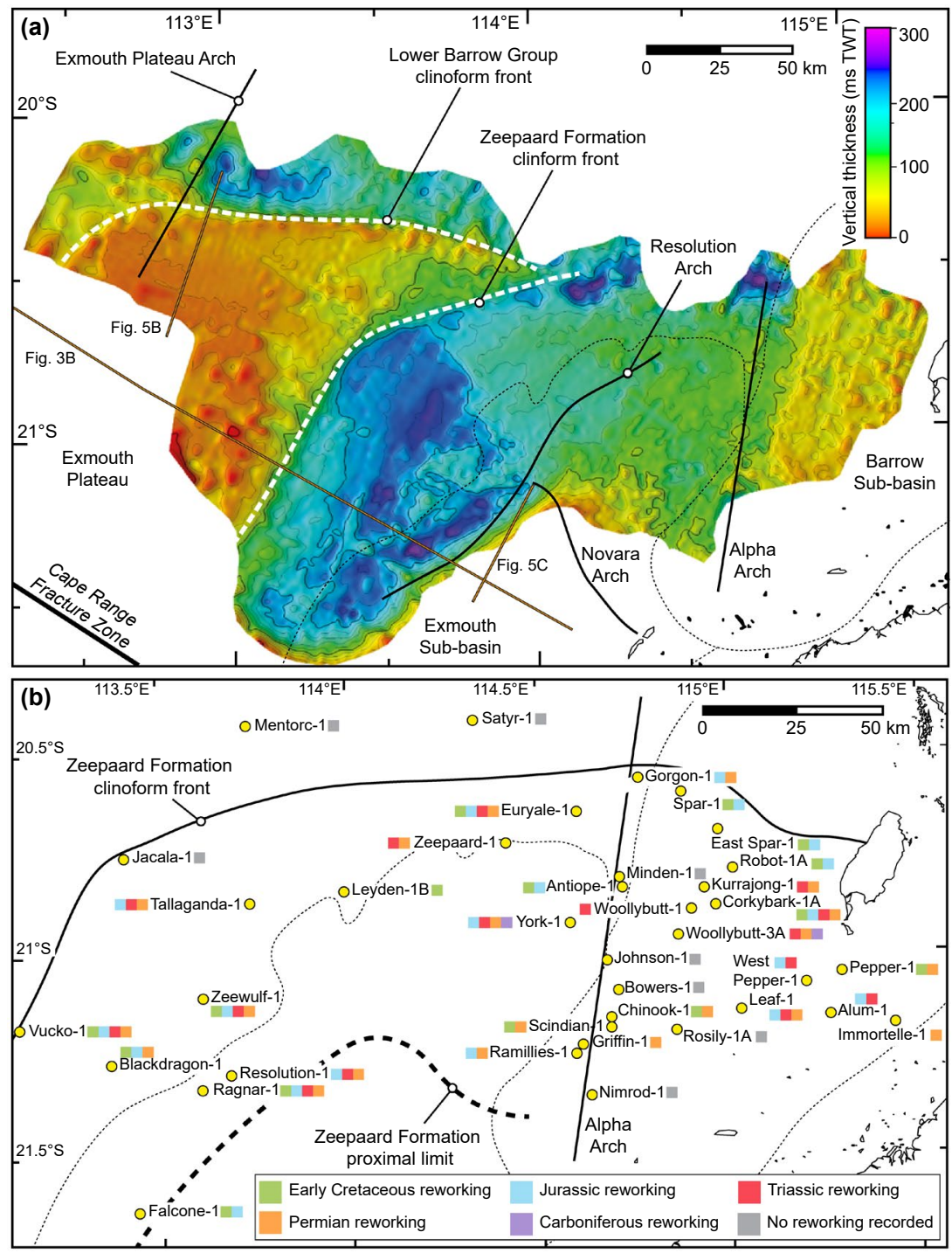

calcareous nannofossil at 133.74 Ma (Figure 6) (e.g. Gard et al., 2016). These distributions of E. striatus and E. windii calcareous nannofossils indicate the IVU formed in the Late Valanginian after $134.98 \mathrm{Ma}$ and some time before 133.74 Ma, more recently than the previously proposed 138.2 Ma (Figure 9) (cf. Helby et al., 1987). Formation of the IVU before $133.74 \mathrm{Ma}$ is supported by the presence of C. cuvillieri and $S$. colligata calcareous nannofossils, which globally last occurred at 132.88 and 132.6 Ma respectively, between the IVUand the TVU in Nimblefoot-1 (Figure 6) (Reeve, 2017). Development of the IVU between 134.98 and $133.74 \mathrm{Ma}$ is also consistent with biostratigraphic constraints on its timing from the North Scarborough-1 borehole, supporting the recalibration of the top to the $S$. areolata dinoflagellate zone as latest Valanginian-toearliest Hauterivian (Figure 9) (Gard et al., 2016).

A maximum age range of 134.98-133.74 Ma for IVU development indicates it formed synchronously to chrons M10N and M10 (135.9-133.6 Ma) within the Gascoyne Margin COTZ and Cuvier Abyssal Plain (Figures 2b, 9,
FI G URE 8 (a) Vertical two-way time thickness map of the Zeepaard and Birdrong Formations based on seismic interpretation. (b) Map showing well locations from the Exmouth Plateau and Exmouth and Barrow Sub-basins where Early Cretaceous, Jurassic, Triassic, Permian and Carboniferous age palynomorphs are recorded within the Zeepaard Formation and 10a) (e.g. Robb et al., 2005). If the Cuvier Abyssal Plain corresponds to a COTZ, similar to the Gascoyne Margin COTZ, the overlap in magnetic chron and IVU ages indicates that uplift and unconformity development occurred before the breakup of both margins in the Hauterivian at ca. 131 Ma (Figures 9 and 10a) (e.g. Direen et al., 2008; Reeve et al., 2021; Robb et al., 2005). Conversely, if the Cuvier Abyssal Plain comprises $\lesssim 136$ Myr old oceanic crust (e.g. Falvey \& Veevers, 1974; Hopper et al., 1992; Larson et al., 1979), an age range of 134.98-133.74 Ma for the IVU indicates it formed: (i) after continental breakup of the Cuvier Margin and during seafloor spreading; and (ii) before continental breakup of the Gascoyne Margin at ca. $131 \mathrm{Ma}$ (Figures 9 and 10a). Regardless of the nature of the Cuvier Abyssal Plain, our age recalibration indicates the IVU did not coincide with continental breakup, i.e. full rupture of continental lithosphere across the whole margin (Figures 9 and 10a) (cf. Arditto, 1993; Helby et al., 1987; Paumard et al., 2018; Romine \& Durrant, 1996). 


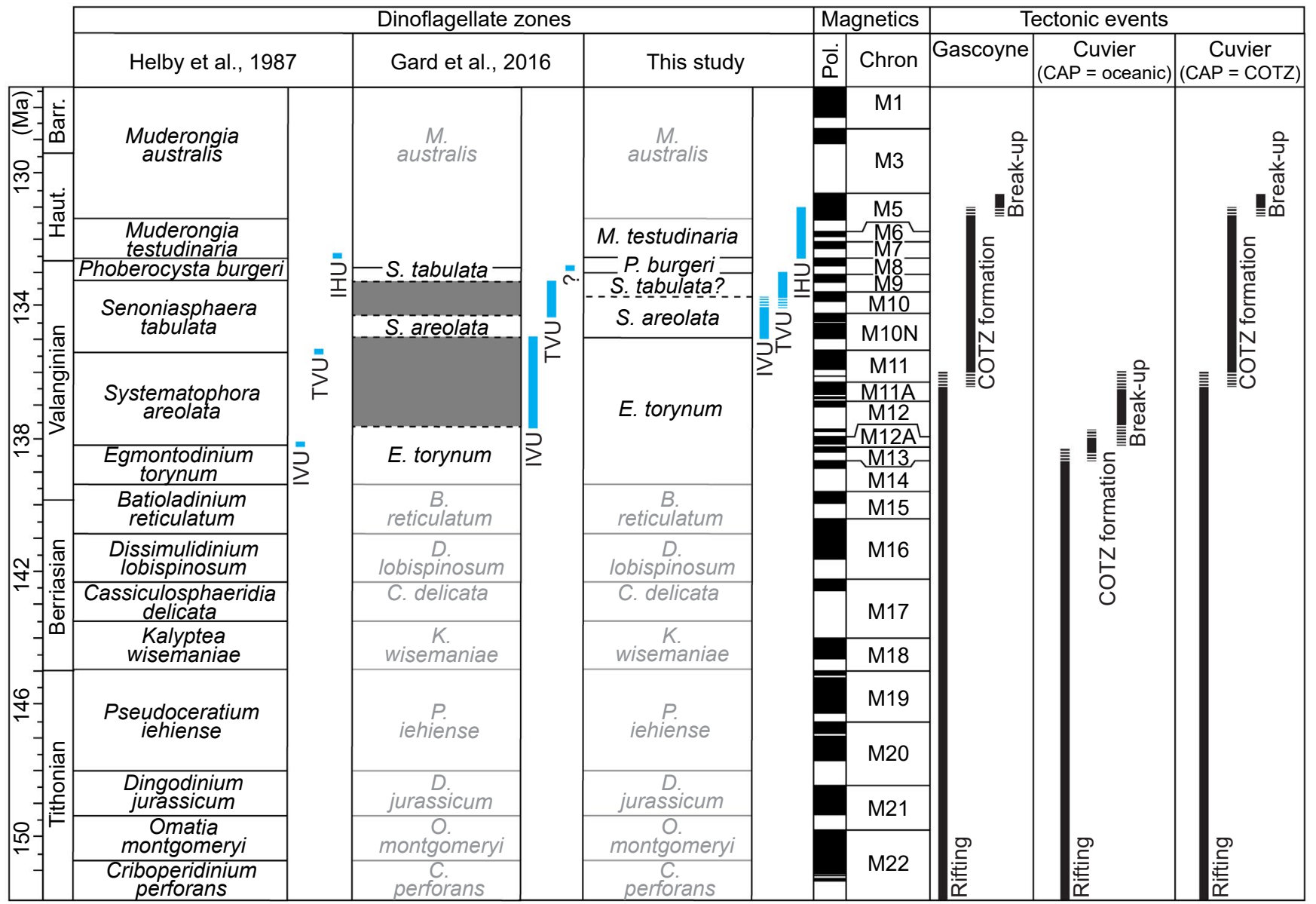

F I G U RE 9 Comparison of previously published dinoflagellate zone ages of Helby et al. (1987) and Gard et al. (2016) to our recalibrated dinoflagellate zone ages. In the North Scarborough-1 borehole, Gard et al. (2016) defined an unnamed unconformity (?), which we interpret as being the IHU. Numerical ages and magnetic polarity chrons (Cohen et al., 2013, updated; Gradstein et al., 2012), in addition to generalised tectono-magmatic evolution of the Gascoyne and Cuvier Abyssal Plains also shown; two scenarios for the Cuvier Abyssal Plain (CAP) are included where it is either oceanic crust of a continent-ocean transition zone (COTZ) (see Reeve et al., 2021 and references therein)

\subsection{2 | TVU age and geodynamic significance}

The TVU corresponds to the boundary between the $S$. areolata and $S$. tabulata dinoflagellate zones, and has previously been interpreted to have either formed in the Valanginian at $134.9 \mathrm{Ma}$ (e.g. Arditto, 1993; Helby et al., 1987) or between 134.32 and $133.29 \mathrm{Ma}$ (Figure 3a) (Gard et al., 2016). The recovery of $E$. windii immediately below the TVU in Lightfinger-1 suggests this unconformity could be younger than $133.74 \mathrm{Ma}$, but only if the presence of this calcareous nannofossil corresponds to its last global occurrence (Figure 6) (e.g. Gard et al., 2016). Similarly, the presence of $C$. cuvillieri and $S$. colligata calcareous nannofossils below the TVU in Nimblefoot-1 suggests the unconformity could be younger 132.88-132.6 Ma, but only if these specimens correspond to their last global occurrence (Figure 6) (Reeve, 2017). However, we note the presence of E. striatus, which globally last appeared at $132.89 \mathrm{Ma}$ (e.g.
Gard et al., 2016), immediately above the TVU within Nimblefoot-1, indicating the unconformity is older than $132.89 \mathrm{Ma}$ (Figures 3b, 7, and 10); i.e. the C. cuvillieri and $S$. colligata calcareous nannofossils do not correspond to their last global occurrence. Constraining the onset and duration of TVU development further is difficult because there are no recognised occurrences of $S$. tabulata palynomorphs within Lightfinger-1 or Nimblefoot-1 (Figure 7), which would be expected to occur in strata immediately above the unconformity (Figures 2a and 7) (e.g. Arditto, 1993; Helby et al., 1987). This lack of $S$. tabulata occurrences may be because the strata hosting the palynomorphs are highly condensed at these borehole locations and thus could have been missed by sampling at $5 \mathrm{~m}$ intervals. Previous studies from the Barrow Subbasin have noted that the $S$. tabulata zone is highly facies dependent and therefore may not be recorded in the Exmouth Plateau due to palaeoenvironmental controls (e.g. Goodall, 1999). Considering our recalibrated 
(a) IVU formation

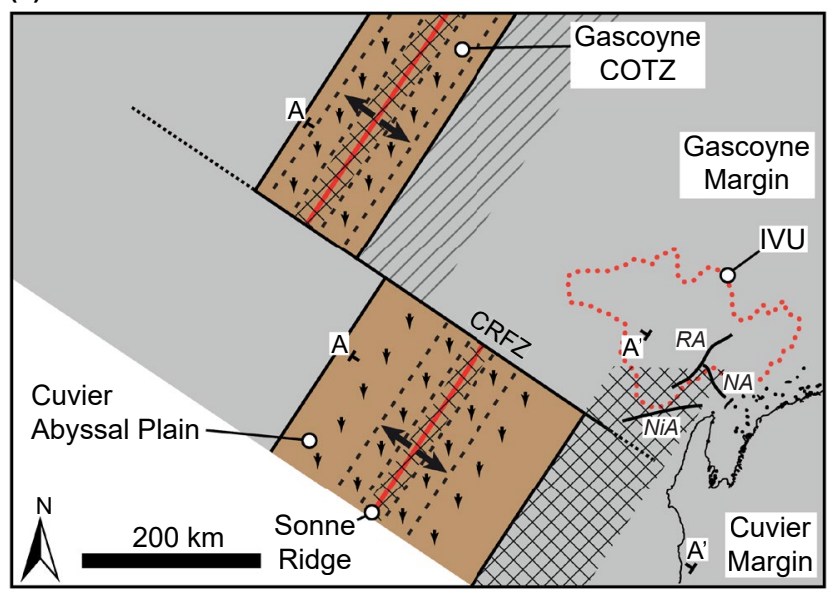

(b) IHU formation

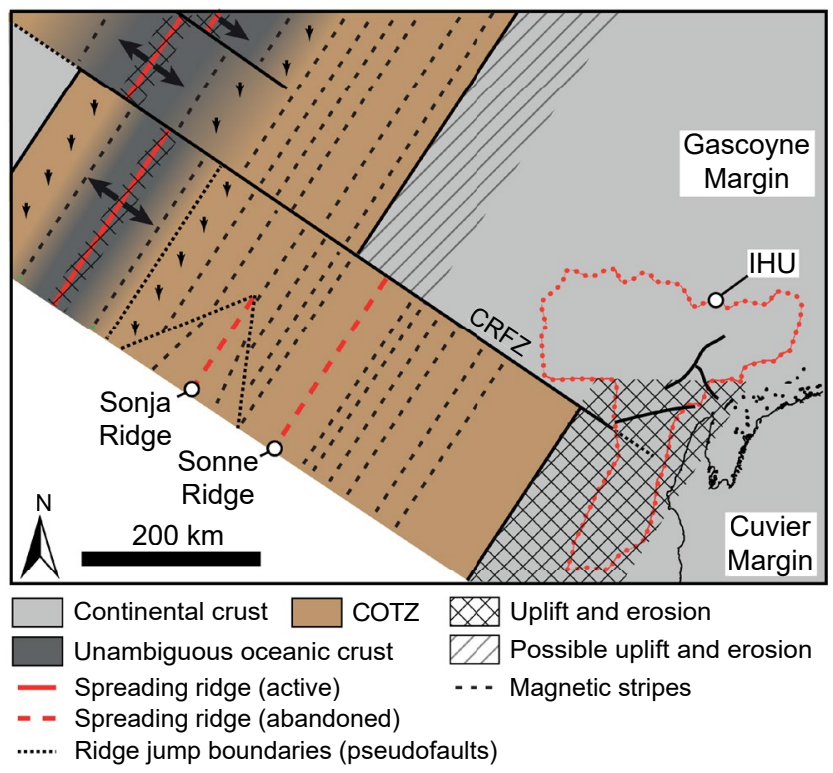

(c) $\mathrm{A}$

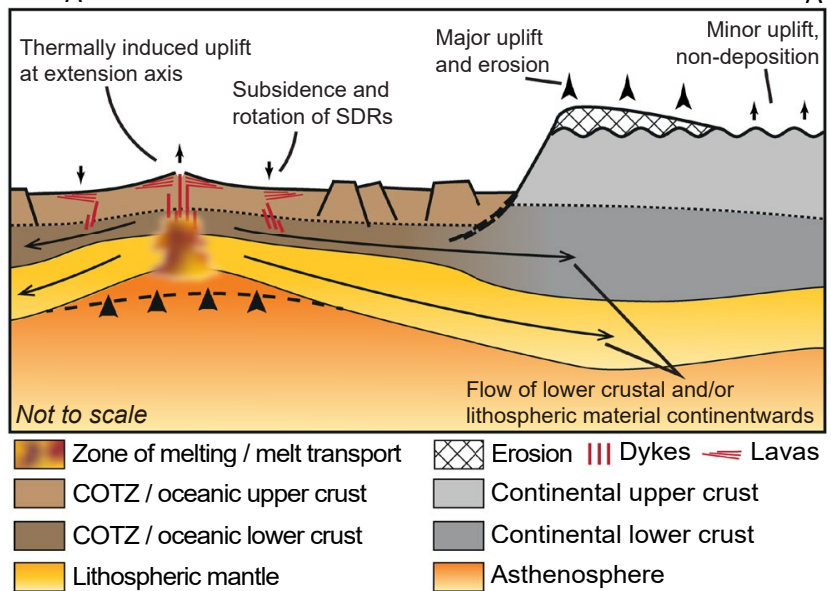

FI G URE 10 (a and b) Schematic palaeogeographic reconstructions showing the development of the IVU and IHU, and areas of associated uplift, with respect to formation of the Gascoyne Margin COTZ and the Cuvier Abyssal Plain (after Reeve et al., 2021) maximum age of the IVU is $134.98 \mathrm{Ma}$ and given that the Zeepaard Formation was deposited between the IVU and TVU, our results indicate the TVU is younger than 134.98 Ma (Figure 9) (cf. Helby et al., 1987). We thus suggest the TVU likely formed between ca. 134 and $133 \mathrm{Ma}$, dependent on when the IVU formed and how long its formation lasted, broadly consistent with dinoflagellate occurrences in the North Scarborough-1 borehole that suggest the $S$. areolata-S. tabulata zone boundary occurred at 133.29 Ma (Figure 9) (Gard et al., 2016).

The potential formation of the TVU at ca. 134133 Ma overlaps with chrons M10-M9 (ca. 134.2133 Ma; Figures 2b, 9, and 10a) (e.g. Robb et al., 2005). If the Cuvier Abyssal Plain corresponds to a COTZ, similar to the Gascoyne Margin COTZ, the overlap in ages of chrons M10, M9 and the TVU indicate uplift and unconformity development occurred before continental breakup of both margins in the Hauterivian at ca. $131 \mathrm{Ma}$ (Figures 9 and 10a) (e.g. Direen et al., 2008; Robb et al., 2005). Conversely, if the Cuvier Abyssal Plain comprises $\lesssim 136$ Myr old oceanic crust (e.g. Falvey \& Veevers, 1974; Hopper et al., 1992; Larson et al., 1979; Reeve et al., 2021), an age range of ca. 134-133 Ma for the TVU indicates it formed: (i) after continental breakup of the Cuvier Margin and during seafloor spreading; and (ii) before continental breakup of the Gascoyne Margin at ca. $131 \mathrm{Ma}$ (Figures 9 and 10a).

\subsubsection{IHU age and geodynamic significance}

The IHU corresponds to the boundary between the $P$. burgeri and $M$. testudinaria dinoflagellate zones, and has previously been interpreted to have formed in the Hauterivian at ca. 132.5 Ma (Figure 3a) (e.g. Helby et al., 1987; Mutterlose, 1992). This inferred age of ca. $132.5 \mathrm{Ma}$ is consistent with the coincidence between the first (ca. $132.5 \mathrm{Ma}$ ) and last (132.89 Ma) occurrences of Z. scutula and E. striatus, respectively, in the P. burgeri dinoflagellate zone of Nimblefoot-1 located ca. $30 \mathrm{~m}$ below the IHU (Figure 7); these calcareous nannofossil occurrences suggest the IHU is younger than $132.5 \mathrm{Ma}$ (Figure 9). We note E. striatus and $C$. cuvillieri calcareous nannofossils are found above the IHU in Lightfinger-1, which both last appeared globally at ca. $132.9 \mathrm{Ma}$, and would imply the unconformity is older than the previously inferred age of $132.5 \mathrm{Ma}$ (Figure 7). However, we suggest these E. striatus and C. cuvillieri calcareous nannofossils have been reworked following erosion of older strata; i.e. the Lightfinger-1 data do not necessarily contradict an IHU age of $\lesssim 132.5 \mathrm{Ma}$. An age of $132.5 \mathrm{Ma}$ for the IHU is also supported by the single specimen of $L$. bolli, which 
has a global range of 133.5-131.5 Ma, in the $M$. testudinaria dinoflagellate zone of Lightfinger-1 above the IHU (Figure 6) (Reeve, 2017). Within the North Scarborough-1 borehole, Gard et al. (2016) dated an unnamed unconformity to 133.29-132.96 Ma, based on the last occurrence of Crucibiscutum salebrosum (132.96 Ma) above the last occurrence of Stradnerlithus silvaradius (133.29 Ma) in strata between depths of 1750 and $1760 \mathrm{~m}$ (Figure 9) (Gard et al., 2016). We re-interpret the North Scarborough-1 palynological data and highlight that the ca. 133 Myr old strata intersected between depths of 1750 and $1760 \mathrm{~m}$, which host the inferred unnamed unconformity, are overlain by rocks belonging to the $M$. australis dinoflagellate zone and are ca. 131-129 Ma in age (Hauterivian-to-Barremian) (Figure 9) (Gard et al., 2016). We therefore interpret that the unnamed unconformity in North Scarborough-1 is actually located above the last occurrence of $C$. salebrosum (132.96 Ma) in the $S$. tabulata dinoflagellate zone, immediately below the ca. 131-129 Ma M. australis dinoflagellate zone, and in fact is the IHU (cf. Gard et al., 2016). Where the IHU forms an angular unconformity across the southern Exmouth Sub-basin and Cuvier Margin, overlying strata also correspond to the $M$. australis dinoflagellate zone (Figures $5 \mathrm{~d}$ and $7 \mathrm{~b}$ ). In summary, we suggest the IHU likely formed in the Hauterivian at some time between ca. 132.5 and 131 Ma (cf. Helby et al., 1987; Mutterlose, 1992).

If our interpretation is correct, the formation of the IHU at ca. 132.5-131 Ma overlaps with chrons M7-M5n (ca. 132.5-130.6 Ma; Figures 2b, 9, and 10a) (e.g. Robb et al., 2005). If the Cuvier Abyssal Plain corresponds to a COTZ, similar to the Gascoyne Margin COTZ, the overlap in ages of chrons M7-M5n and the IHU indicates that uplift and unconformity development likely occurred immediately before or during continental breakup of both margins in the Hauterivian at ca. $131 \mathrm{Ma}$ (Figures 9 and 10a) (e.g. Direen et al., 2008; Reeve et al., 2021; Robb et al., 2005). Conversely, if the Cuvier Abyssal Plain comprises $\lesssim 136$ Myr old oceanic crust (e.g. Falvey \& Veevers, 1974; Hopper et al., 1992; Larson et al., 1979), an age range of ca. 132.5-131 Ma for the IHU indicates it formed: (i) after continental breakup of the Cuvier Margin and during seafloor spreading, broadly coincident with ridge jumps from the Sonne Ridge to the Sonja Ridge, and onto a spreading centre near Greater India (Robb et al., 2005); and (ii) immediately before or during continental breakup of the Gascoyne Margin at ca. 131 Ma (Figures 9 and 10a).

\section{2 | Uplift distribution during unconformity formation}

Calibrating the timing of unconformity development is critical to interpreting how they relate temporally to continental breakup, but does not permit unambiguous constraint of the actual mechanisms driving their formation. Here, we discuss how the distribution of uplift, erosion and non-deposition during IVU and IHU development spatially relate to the contemporaneous breakup events identified above (Figure 10). Specifically, we use the seismic character of the unconformities, the age of sub- and supercropping strata, and the distribution of palynomorph reworking to map areas of uplift and erosion.

Across most of the Exmouth Plateau, northern Exmouth Sub-basin, and Barrow Sub-basin extent, the IVU and IHU appear as disconformities (Figures 4c and 5a,b); where the intervening TVU is recognised in seismic reflection data, its character mirrors that of the underlying IVU (e.g. Figure 5c). Strata beneath the IVU, which corresponds to the Valanginian E. torynum-S. areolata dinoflagellate zone boundary, typically belong to the Barrow Group and Valanginian E. torynum, or occasionally the Berriasian-to-Valanginian $B$. reticulatum, dinoflagellate zone (Figure $7 \mathrm{a}$ ). These occurrences of E. torynum and B. reticulatum dinoflagellate zone subcrop ages indicate IVU development here involved little or no uplift and erosion; i.e. it marks a period of non-deposition. Strata above the IVU typically correspond to the Zeepaard Formation and Valanginianto-Hauterivian $S$. areolata dinoflagellate zone, indicating the duration of unconformity formation was relatively short (Figure $7 \mathrm{~b}$ ). Close to the Australian coast along the eastern portion of the Barrow Sub-basin and the Peedamullah Shelf, the IVU appears to overlie Permian-to-Jurassic strata; here, the IVU merges with older unconformities and is overlain by the Zeepaard Formation to Muderong Shale (Figure 7). Merging of the IVU with older unconformities, such as those developed during the Callovian (Jitmahantakul \& McClay, 2013), makes it difficult to establish how much uplift and erosion occurred here in the Valanginian (i.e. immediately prior to and explicitly associated with breakup). These variations in IVU subcrop and supercrop in the Barrow Sub-basin and Peedamullah Shelf (Figure 7) may also reflect the autogenic erosional and depositional history of the shallow marine setting characterising these regions, rather breakup related crustal dynamics.

Broadly southwards of the intersection between the Resolution and Novara arches, the IVU and IHU become angular unconformities (Figures $4 \mathrm{c}$ and $5 \mathrm{c}$,d). For example, the IVU is recognised in seismic reflection data as an angular unconformity across an E-trending belt parallel to and $>20 \mathrm{~km}$ north of the Ningaloo Arch (Figures $4 \mathrm{c}$ and $5 \mathrm{c}$ ). Sparse well data in this area reveal IVU sub-crop ages range from Upper Jurassic to the Berriasian-to-Valanginian $B$. reticulatum dinoflagellate zone of the Barrow Group, indicating the 
degree of erosion was spatially variable (Figure 7a). South of this zone, the IHU, which likely corresponds to the Hauterivian P. burgeri-M. testudinaria dinoflagellate zone boundary, erodes into the Tithonian-toValanginian Barrow Group over the Novara Arch and Triassic-to-Jurassic strata across the Carnarvon Terrace (Figure 7a); from these data we thus cannot ascertain whether the underlying IVU originally extended further south (Figure 10a). Strata above the IHU, where it corresponds to an angular unconformity, belong to the Hauterivian-to-Barremian M. australis or O. operculata dinoflagellate zones (Figure $7 \mathrm{~b}$ ). These supercrop data indicate strata from the Hauterivian $M$. testudinaria dinoflagellate zone, which directly overlie the IHU to the north (e.g. in Lightfinger-1 and Nimblefoot-1), are missing across this southern area of the margin. Our seismic reflection mapping and analysis of sub- and supercrop ages suggest that the onset of IHU formation occurred simultaneously across the study area, but only involved significant uplift and erosion south of the intersection between the Resolution and Novara arches; i.e. north of this area the IHU marks a period of nondeposition (Figure 10b). We also show deposition onto the IHU resumed in the Hauterivian (M. testudinaria dinoflagellate zone) across most of the Exmouth Plateau, northern Exmouth Sub-basin and Barrow Sub-basin, but to the south deposition resumed later in the Late Hauterivian-to-Barremian (M. australis dinoflagellate zone) (Figure $7 b$ ). We cannot determine whether this diachroneity in the resumption of deposition indicates uplift and erosion in the southern half of our study area was maintained throughout the time gap represented by the IHU, or whether there was a lag between the end of uplift and the onset of deposition.

In addition to delimiting sub- and supercrop ages, highresolution spatial and temporal constraints on uplift distribution are preserved in the provenance of reworked strata, if the erosion of uplifted areas produces sedimentary deposits containing diagnostic compositional and microfossil assemblages (e.g. Reeve et al., 2016). The Zeepaard Formation clinoforms were deposited onto the IVU, prograded northwards, and were sourced from rocks hosting Early Cretaceous (Barrow Group), Jurassic, Triassic and Permian palynomorphs (Figure 8). Compared with the underlying, pervasively reworked Barrow Group, the degree of reworking in the Zeepaard Formation is lower (e.g. Reeve et al., 2016), implying the two stratal units may have had different source areas; i.e. the formation of the IVU may have coincided with a change in regional uplift, erosion and/or sediment dispersal patterns. Reeve et al. (2016) attributed prominent reworking of Permian and Triassic palynomorphs in the $r$ Barrow Group to prebreakup uplift of the South Carnarvon Basin. Based on the decrease in reworking abundance at the base of the Zeepaard Formation, we interpret that: (i) the rate of uplift of the South Carnarvon Basin, and thus erosion of Permian and Triassic strata, decreased during or immediately after IVU formation; and (ii) the Zeepaard Formation was likely formed, at least partially, by recycling of Lower Cretaceous Barrow Group, which contained previously reworked Jurassic-Permian palynomorphs (e.g. Reeve et al., 2016).

Overall, the localised angular character of the IVU, coupled with the areal coverage of and palynomorph distribution within the northward-prograding Zeepaard Formation, suggests: (i) little or no uplift occurred across most of the Exmouth Plateau, northern Exmouth Sub-basin and Barrow Sub-basin; (ii) uplift occurred at and south of the Novara Arch and southern half of the Resolution Arch; and (iii) erosion of the uplifted Barrow Group and its correlative strata to the south provided material for the Zeepaard Formation (Figure 10a). Our interpretation of uplift distribution during IVU development supports previous suggestions that formation and erosion of the Ningaloo Arch sourced the Zeepaard Formation (Figure 10a) (Tindale et al., 1998). The Resolution and Novara arches have previously been linked to Santonianto-Oligocene inversion (Tindale et al., 1998), but their apparent role in the formation of the IVU suggests they may have initially formed in the Valanginian and were later reactivated (Figure 10a). The distribution of uplift, erosion and non-deposition during IHU formation seems to mirror that of the IVU (Figure 10b).

\section{3 | Possible mechanisms of breakup unconformity development}

Breakup unconformities are typically considered to develop during continental breakup and the onset of seafloor spreading, in response to uplift driven by mantle upwelling, depth-dependent extension and/or isostatic rebound (e.g. Braun \& Beaumont, 1989; Cochran, 1983; Falvey, 1974; Issler et al., 1989; Morley, 2016; White \& McKenzie, 1988). Having calibrated the ages of unconformity development, which allow us to identify contemporaneous tectonic events, we can use our interpreted uplift distributions to explore possible mechanisms driving their formation (e.g. Gong et al., 2019).

Our recalibrated ages suggest the IVU (134.98133.74 Ma) developed coincident to the generation of chrons M10N and M10 (135.9-133.6 Ma), during early formation of the Gascoyne Margin COTZ and the Cuvier Abyssal Plain (Figures 9 and 10a). These temporal relationships suggest the IVU may have formed during the localisation of extension along narrow continental rift zones 
(Gascoyne and possibly Cuvier margin), which may ultimately become COTZs (e.g. as inferred by Bridges et al., 2012 for the onshore Gulf of Aden rift, Ethiopia), and perhaps along a seafloor spreading centre within the Cuvier Abyssal Plain. This localisation of extension was associated with an increase in magmatism that produced the igneous rocks carrying the M10N-M10 magnetic chron signature (e.g. as inferred by Collier et al., 2017 along the South Atlantic rifted margin). Specifically, we suggest that IVU formation occurred when rifting, which was initially distributed across the Exmouth Plateau and involved minor faulting (Stagg et al., 2004), localised along areas that became the Gascoyne, and possibly Cuvier, COTZs. Similar migration (from inboard to outboard positions) and localisation of extension through time has been recognised from both active rifts and ancient rifted margins, where narrow zones of extension play an important role in the late stages of rifting and transition to seafloor spreading (e.g. Bastow et al., 2018; Bastow \& Keir, 2011; Corti, 2009; Ebinger \& Casey, 2001; Geoffroy, 2005; PérezGussinyé et al., 2020; Peron-Pinvidic et al., 2019).

The presence of seaward-dipping reflector (SDR) lava sequences observed across chrons M10N and M10 in both the Gascoyne Margin COTZ and Cuvier Abyssal Plain (Direen et al., 2008; Reeve et al., 2021), indicates that as crust moved away from the elevated extension axis it subsided and created space for SDR emplacement (Figure 11) (e.g. Buck, 2017; Corti et al., 2015; Paton et al., 2017). Our analysis shows uplift and erosion was focussed along the continental Cuvier Margin during subsidence of the Gascoyne Margin COTZ and Cuvier Abyssal Plain as they moved away from the extension axis (Figure 10a); we lack sufficient data to determine whether uplift also occurred along the distal Gascoyne Margin adjacent to its COTZ (Figure 10a). We thus suggest unconformity development likely reflects localised rift flank uplift (Pérez-Gussinyé et al., 2020) and consider two possible principal mechanisms that may both have contributed to uplift. Firstly, crustal loading at the rift axis related to voluminous extrusive activity and SDR formation can drive plate flexure (e.g. Buck, 2017; Corti et al., 2015). Such flexural bending accommodates subsidence beneath the load, but induces minor uplift across a broad area beyond the load limits (Figure 11) (e.g. Buck, 2017; Corti et al., 2015). Rift flank uplift can also be driven by depth-dependent extension following strain localisation along rift zones in the Gascoyne Margin COTZ and Cuvier Abyssal Plain; i.e. lower crustal and/or lithospheric material flowed landward away from rift axis and subsiding COTZ to under the rift flanks (Figure 11). Models involving depth-dependent extension have previously been proposed to explain the architecture and subsidence history of the Gascoyne Margin (Driscoll \& Karner, 1998; Frey et al., 1998; Huismans \& Beaumont,
2011; Reeve et al., 2016; Stagg et al., 2004; Stagg \& Colwell, 1994). Given the apparent temporal coincidence between magmatism and rift flank uplift, it seems plausible to suggest that transient depth-dependent extension could have been instigated by intrusion-induced heating of the lower crust (Daniels et al., 2014). We propose that both the flexural uplift and depth-dependent extension contributed to driving the observed uplift patterns recorded by and captured in the distribution of the IVU, by inducing marginwide uplift and unconformity development, peaking along the Exmouth Plateau, Exmouth Sub-basin and Carnarvon Terrace areas. Small-scale mantle convection generated at the boundary between the thicker Gascoyne lithosphere and the thinner Cuvier lithosphere may also have contributed to uplift of the Cuvier Margin (e.g. Müller et al., 2002).

Our recalibrated age of ca. 134-133 Ma for the TVU suggests that it formed during development of the Gascoyne Margin COTZ, and seafloor spreading or COTZ development of the Cuvier Abyssal Plain (Figure 9). We lack constraints on uplift distribution during formation of the TVU, although we suggest its development may have been related to an increase in dyking and, thus, enhanced magma-assisted extension. Such dyking could plausibly have led to the generation of new magmatic crust (i.e. no continental crust present) along sub-aerial, or perhaps shallow-marine, spreading ridges in the COTZ(s) (Collier et al., 2017; McDermott et al., 2018; Paton et al., 2017).

Our recalibrated ages suggest the IHU (ca. 132.5$131 \mathrm{Ma}$ ) probably developed simultaneously to the formation of chrons M7-M5n (ca. 132.5-130.6 Ma), likely coinciding with the onset of full continental lithosphere rupture along the Gascoyne Margin, and perhaps the Cuvier Margin (Figures 2b, 9, and 10a). The IHU therefore seems to best fit the classic interpretation of a breakup unconformity as forming at the onset of seafloor spreading (e.g. Falvey, 1974; Soares et al., 2012). We note that the distribution of disconformable and angular portions of the IHU broadly mirror those of the IVU, suggesting uplift was again focussed along the rift flanks within the continental margins (Figure 11).

Overall, our work supports previous findings that continental breakup processes are variable in time and space, and can involve multiple episodes of uplift and unconformity development (e.g. Alves \& Cunha, 2018; Gong et al., 2019; Monteleone et al., 2019; Soares et al., 2012; Xie et al., 2019). We also demonstrate that migration of rift axes probably plays an important role in controlling the occurrence, distribution and magnitude of breakup unconformities (Pérez-Gussinyé et al., 2020). Stratigraphic successions on continental rifted margins provide a critical record of these complex breakup processes, but unlocking these archives can be challenging 


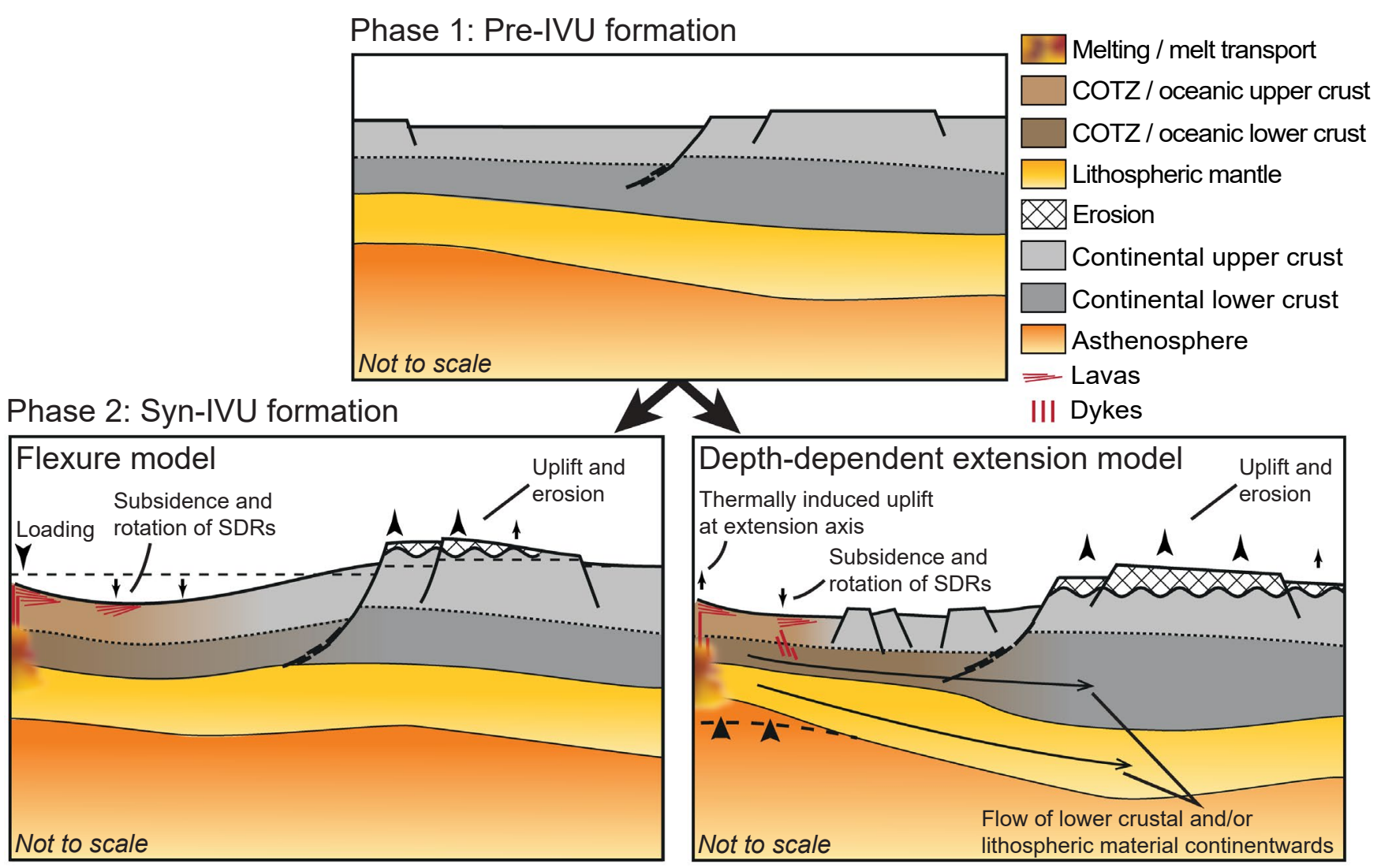

F I G U RE 11 Schematic sections showing how magma-dominated extension along a rift axis or spreading centre could promote: (i) crustal flexure whereby the rift axis subsides and rift flanks uplift by a small amount across a broad area (e.g. Buck, 2017; Corti et al., 2015); and (ii) lower crustal and/or lithospheric mantle to flow whereby material accumulates beneath the continental margin rift flank, causing it to uplift. SDRs, seaward-dipping reflectors

and requires integrating geological, geophysical and biostratigraphic analyses (e.g. Gong et al., 2019; Monteleone et al., 2019; Pérez-Gussinyé et al., 2020; Peron-Pinvidic et al., 2019; Soares et al., 2012).

\section{6 | CONCLUSIONS}

Breakup unconformities are common features observed along rifted margins and are typically assumed to occur at the onset of seafloor spreading, potentially in response to uplift driven by asthenospheric upwelling, isostatic rebound and/or depth-dependent extension. Using an integrated geological and geophysical approach, we present a regional-scale interpretation of the stratigraphic expression of continental breakup in the North Carnarvon Basin, offshore NW Australia, and discuss its implications for margin evolution. During the breakup of the Gascoyne and Cuvier margins, three unconformities developed over ca. $4 \mathrm{Myr}$, rather than a single 'breakup unconformity' sensu stricto. Our recalibration of high-resolution biostratigraphic data constrain the timing of these unconformities and allows us to relate their genesis to the tectonic record preserved in the magnetic stripes of adjacent continent-ocean transition zones (COTZs) and oceanic crust. We find that: (i) the IVU developed between 134.98 and $133.74 \mathrm{Ma}$, not at $138.2 \mathrm{Ma}$ as previously suggested, broadly coincident with localisation of strain to narrow, magmarich rift zones during continent-ocean transition, and possibly seafloor spreading; (ii) the TVU likely formed at ca. 134-133 Ma, perhaps in response to sub-aerial magmatic spreading within COTZs; and (iii) the IHU probably formed between ca. 132.5 and 131 Ma during the onset of full lithospheric rupture of the Gascoyne, and perhaps Cuvier, margins. By mapping unconformity subcrop and supercrop ages, coupled with examining thickness variations and palynomorph reworking within the inter-unconformity Zeepaard Formation, we demonstrate uplift and erosion was focussed along the continental Cuvier Margin, adjacent to its COTZ. The unconformities across most of the Gascoyne Margin are disconformable and likely reflect non-deposition rather than uplift and erosion. We speculate that localisation of uplift occurred along the rift flanks due to flexural bending of the crust, driven by extrusive loading along 
the rift axis, and periodic depth-dependent extension during COTZ and perhaps oceanic crust formation. Our work shows that the 'breakup unconformity' is not necessarily a single, simple stratigraphic surface related to the onset of oceanic crust formation, but may instead be represented by multiple unconformities reflecting a complex history of uplift and subsidence during the transition from continental rifting to seafloor spreading.

\section{ACKNOWLEDGEMENTS}

The authors thank Schlumberger for provision of Petrel licenses to Imperial College London. Geoscience Australia and the Department of Mines and Petroleum are thanked for provision of data. M. T. R. was supported by NERC grant NE/L501621/L. Gwenn Peron-Pinvidic, Gareth Roberts and Saskia Goes are thanked for helpful discussions during the preparation of this manuscript.

\section{PEER REVIEW}

The peer review history for this article is available at https://publons.com/publon/10.1111/bre.12656.

\section{DATA AVAILABILITY STATEMENT}

Seismic reflection and well data used in this study are available from the WAPIMS (https://wapims.dmp. wa.gov.au/wapims/) and NOPIMS (https://www.nopims. gov.au/) data repositories.

\section{ORCID}

Craig Magee (1) https://orcid.org/0000-0001-9836-2365

Ian D. Bastow (ib https://orcid.org/0000-0003-1468-9278

\section{REFERENCES}

Alves, T. M., \& Cunha, T. A. (2018). A phase of transient subsidence, sediment bypass and deposition of regressive-transgressive cycles during the breakup of Iberia and Newfoundland. Earth and Planetary Science Letters, 484, 168-183.

Amante, C., \& Eakins, B. W. (2009). ETOPO1 arc-minute global relief model: Procedures, data sources and analysis. National Oceanic and Atmospheric Administration.

Arditto, P. A. (1993). Depositional sequence model for the postBarrow Group Neocomian succession, Barrow and Exmouth sub-basins, Western Australia. The APPEA Journal, 33, 151-160.

Baillie, P., \& Jacobson, E. (1995). Structural evolution of the Carnarvon Terrace, Western Australia. The APPEA Journal, 35, 321-332.

Bastow, I. D., Booth, A. D., Corti, G., Keir, D., Magee, C., Jackson, C. A. L., Warren, J., Wilkinson, J., \& Lascialfari, M. (2018). The development of late-stage continental breakup: Seismic reflection and borehole evidence from the Danakil Depression, Ethiopia. Tectonics, 37, 2848-2862. https://doi.org/10.1029/2017T C004798

Bastow, I. D., \& Keir, D. (2011). The protracted development of the continent-ocean transition in Afar. Nature Geoscience, 4, $248-250$.
Black, M., McCormack, K., Elders, C., \& Robertson, D. (2017). Extensional fault evolution within the Exmouth Sub-basin, North West Shelf, Australia. Marine and Petroleum Geology, 85, 301-315.

Bott, M. H. (1982). The mechanism of continental splitting. Tectonophysics, 81, 301-309.

Boyd, R., Williamson, P., \& Haq, B. (1993). Seismic stratigraphy and passive-margin evolution of the southern Exmouth plateau. In H. Posamentier, C. Summerhayes, B. Haq, \& G. Allen (Eds.), Sequence stratigraphy and facies associations (pp. 579-603). Blackwell Publishing Ltd.

Braun, J., \& Beaumont, C. (1989). A physical explanation of the relation between flank uplifts and the breakup unconformity at rifted continental margins. Geology, 17, 760-764.

Bridges, D. L., Mickus, K., Gao, S. S., Abdelsalam, M. G., \& Alemu, A. (2012). Magnetic stripes of a transitional continental rift in Afar. Geology, 40, 203-206.

Buck, W. R. (2017). The role of magmatic loads and rift jumps in generating seaward dipping reflectors on volcanic rifted margins. Earth and Planetary Science Letters, 466, 62-69.

Cande, S. C., \& Mutter, J. C. (1982). A revised identification of the oldest sea-floor spreading anomalies between Australia and Antarctica. Earth and Planetary Science Letters, 58, 151-160.

Cochran, J. R. (1983). Effects of finite rifting times on the development of sedimentary basins. Earth and Planetary Science Letters, 66, 289-302.

Cohen, K. M., Finney, S. C., Gibbard, P. L., \& Fan, J.-X. (2013, updated). The ICS international chronostratigraphic chart. Episodes, 36, 199-204.

Collier, J. S., McDermott, C., Warner, G., Gyori, N., Schnabel, M., McDermott, K., \& Horn, B. W. (2017). New constraints on the age and style of continental breakup in the South Atlantic from magnetic anomaly data. Earth and Planetary Science Letters, 477, 27-40.

Colwell, J., Symonds, P., \& Crawford, A. (1994). The nature of the Wallaby (Cuvier) Plateau and other igneous provinces of the west Australian margin. Journal of Australian Geology and Geophysics, 15, 137-156.

Corti, G. (2009). Continental rift evolution: From rift initiation to incipient break-up in the Main Ethiopian Rift, East Africa. EarthScience Reviews, 96, 1-53.

Corti, G., Agostini, A., Keir, D., Van Wijk, J., Bastow, I. D., \& Ranalli, G. (2015). Magma-induced axial subsidence during final-stage rifting: Implications for the development of seaward-dipping reflectors. Geosphere, 11, 563-571. https://doi.org/10.1130/ GES01076.1

Dafoe, L. T., Keen, C. E., Dickie, K., \& Williams, G. L. (2017). Regional stratigraphy and subsidence of Orphan Basin near the time of breakup and implications for rifting processes. Basin Research, 29, 233-254.

Daniels, K. A., Bastow, I. D., Keir, D., Sparks, R. S. J., \& Menand, T. (2014). Thermal models of dyke intrusion during development of continent-ocean transition. Earth and Planetary Science Letters, 385, 145-153. https://doi.org/10.1016/j. eps1.2013.09.018

Direen, N. G., Stagg, H. M. J., Symonds, P. A., \& Colwell, J. B. (2008). Architecture of volcanic rifted margins: New insights from the Exmouth-Gascoyne margin, Western Australia. Australian Journal of Earth Sciences, 55, 341-363. https://doi. org/10.1080/08120090701769472 
Driscoll, N. W., Hogg, J. R., Christie-Blick, N., \& Karner, G. D. (1995). Extensional tectonics in the Jeanne d'Arc Basin, offshore Newfoundland: Implications for the timing of break-up between Grand Banks and Iberia. Geological Society, London, Special Publications, 90, 1-28.

Driscoll, N. W., \& Karner, G. D. (1998). Lower crustal extension across the Northern Carnarvon basin, Australia: Evidence for an eastward dipping detachment. Journal of Geophysical Research: Solid Earth (1978-2012), 103, 4975-4991.

Ebinger, C. J., \& Casey, M. (2001). Continental breakup in magmatic provinces: An Ethiopian example. Geology, 29, 527-530. https:// doi.org/10.1130/0091-7613(2001)029<0527:cbimpa >2.0.co;2

Embry, A. F., \& Dixon, J. (1990). The breakup unconformity of the Amerasia Basin, Arctic Ocean: Evidence from arctic Canada. Geological Society of America Bulletin, 102, 1526-1534.

Falvey, D. A. (1974). The development of continental margins in plate tectonic theory. The APPEA Journal, 14, 95-106.

Falvey, D., \& Veevers, J. (1974). Physiography of the Exmouth and Scott plateaus, western Australia, and adjacent northeast Wharton Basin. Marine Geology, 17, 21-59.

Franke, D. (2013). Rifting, lithosphere breakup and volcanism: Comparison of magma-poor and volcanic rifted margins. Marine and Petroleum Geology, 43, 63-87.

Frey, Ø., Planke, S., Symonds, P. A., \& Heeremans, M. (1998). Deep crustal structure and rheology of the Gascoyne volcanic margin, western Australia. Marine Geophysical Researches, 20, 293-311.

Gard, G., Backhouse, J., \& Crux, J. (2016). Calibration of Early Cretaceous dinoflagellate zones from the NWS of Australia to the global time scale through calcareous nannofossils. Cretaceous Research, 61, 180-187. https://doi.org/10.1016/j.cretres.2016.01.001

Geoffroy, L. (2005). Volcanic passive margins. Comptes Rendus Geoscience, 337, 1395-1408. https://doi.org/10.1016/j. crte.2005.10.006

Gillard, M., Autin, J., Manatschal, G., Sauter, D., Munschy, M., \& Schaming, M. (2015). Tectonomagmatic evolution of the final stages of rifting along the deep conjugate Australian-Antarctic magma-poor rifted margins: Constraints from seismic observations. Tectonics, 34, 753-783. https://doi.org/10.1002/2015T C003850

Gong, Y., Lin, C., Zhang, Z., Zhang, B. O., Shu, L., Feng, X., Hong, F., Xing, Z., Liu, H., \& Su, E. (2019). Breakup unconformities at the end of the early Oligocene in the Pearl River Mouth Basin, South China Sea: Significance for the evolution of basin dynamics and tectonic geography during rift-drift transition. Marine Geophysical Research, 40, 371-384. https://doi.org/10.1007/ s11001-018-9375-2

Goodall, J. (1999). Palynological review of East Spar and Spar-1.

Gradstein, F. M., Ogg, J. G., Schmitz, M. B., \& Ogg, G. M. (2012). The geologic time scale 2012. Elsevier.

Heine, C., \& Müller, R. (2005). Late Jurassic rifting along the Australian North West Shelf: Margin geometry and spreading ridge configuration. Australian Journal of Earth Sciences, 52, 27-39.

Helby, R., Morgan, R., \& Partridge, A. (1987). A palynological zonation of the Australian Mesozoic. Memoir of the Association of Australasian Palaeontologists, 4, 1-94.

Hocking, R. (1992). Jurassic deposition in the southern and central North West Shelf (Vol. 199217). Geological Survey Western Australia Record.
Hocking, R. M., Moors, H. T., \& Van de Graaff, W. E. (1987). Geology of the Carnarvon Basin, Western Australia. State Print. Division.

Hopper, J. R., Mutter, J. C., Larson, R. L., \& Mutter, C. Z. (1992). Magmatism and rift margin evolution: Evidence from northwest Australia. Geology, 20, 853-857. https://doi.org/10.1130/00917613(1992)020<0853:MARMEE > 2.3.CO;2

Huang, C.-Y., Shea, K.-H., \& Li, Q. (2017). A foraminiferal study on Middle Eocene-Oligocene break-up unconformity in northern Taiwan and its correlation with IODP Site U1435 to constrain the onset event of South China Sea opening. Journal of Asian Earth Sciences, 138, 439-465. https://doi.org/10.1016/j. jseaes.2016.09.014

Huismans, R., \& Beaumont, C. (2011). Depth-dependent extension, two-stage breakup and cratonic underplating at rifted margins. Nature, 473, 74-78.

Issler, D., McQueen, H., \& Beaumont, C. (1989). Thermal and isostatic consequences of simple shear extension of the continental lithosphere. Earth and Planetary Science Letters, 91, 341-358.

Jablonski, D. (1997). Recent advances in the sequence stratigraphy of the Triassic to Lower Cretaceous succession in the Northern Carnarvon Basin, Australia. The APPEA Journal, 37, 429-454. https://doi.org/10.1071/AJ96026

Jitmahantakul, S., \& McClay, K. (2013). Late Triassic - Mid-Jurassic to Neogene extensional fault systems in the Exmouth Subbasin, Northern Carnarvon Basin, North West Shelf, Western Australia. In M. Keep \& S. J. Moss (Eds.), The sedimentary basins of Western Australia IV: Proceedings of the Petroleum Exploration Society of Australia Symposium, Perth, WA, 2013.

Labutis, V. (1994). Sequence stratigraphy and the North West Shelf of Australia. In P. Purcell \& R. Purcell (Eds.), The sedimentary basins of Western Australia: Proceedings of the Petroleum Exploration Society of Australia Symposium (pp. 159-180).

Larsen, H., \& Saunders, A. (1998). 41. Tectonism and volcanism at the Southeast Greenland rifted margin: A record of plume impact and later continental rupture. Proceedings of the Ocean Drilling Program, Scientific Results (pp. 503-533).

Larson, R. L., Mutter, J. C., Diebold, J. B., Carpenter, G. B., \& Symonds, P. (1979). Cuvier Basin: A product of ocean crust formation by Early Cretaceous rifting off Western Australia. Earth and Planetary Science Letters, 45, 105-114.

Lavin, C. (1997). The Maastrichtian breakup of the Otway Basin Margin-A model developed by integrating seismic interpretation, sequence statigraphy and thermochronological studies. Exploration Geophysics, 28, 252-259. https://doi.org/10.1071/ EG997252

Le Pichon, X., \& Sibuet, J. C. (1981). Passive margins: A model of formation. Journal of Geophysical Research: Solid Earth, 86, 3708-3720.

Longley, I., Buessenschuett, C., Clydsdale, L., Cubitt, C., Davis, R., Johnson, M., Marshall, N., Murray, A., Somerville, R., Spry, T. B., \& Thompson, N. B. (2002). The North West Shelf of Australia-A Woodside perspective. In M. Keep \& S. J. Moss (Eds.), The sedimentary basins of Western Australia (Vol. 3, pp. 27-88). Proceedings West Australian Basins Symposium.

Marshall, N., \& Lang, S. (2013). A new sequence stratigraphic framework for the North West Shelf, Australia. The sedimentary basins of Western Australia 4: Proceedings PESA Symposium, Perth (pp. 1-32).

McClay, K., Scarselli, N., \& Jitmahantakul, S. (2013). Igneous intrusions in the Carnarvon Basin, NW Shelf, Australia. In M. Keep 
\& S. J. Moss (Eds.), The sedimentary basins of Western Australia IV. Proceedings of the Petroleum Exploration Society of Australia Symposium, Perth, WA.

McDermott, C., Lonergan, L., Collier, J. S., McDermott, K. G., \& Bellingham, P. (2018). Characterization of seaward-dipping reflectors along the South American Atlantic margin and implications for continental breakup. Tectonics, 37, 3303-3327.

McKenzie, D. (1978). Some remarks on the development of sedimentary basins. Earth and Planetary Science Letters, 40, 25-32.

Menzies, M., Klemperer, S., Ebinger, C., \& Baker, J. (2002). Characteristics of volcanic rifted margins. In M. Menzies, S. Klemperer, C. Ebinger, \& J. Baker (Eds.), Volcanic rifted margins, Special Publications (Vol. 362, pp. 1-14). Geological Society of America.

Miall, A. D. (2016). The valuation of unconformities. Earth-Science Reviews, 163, 22-71.

Mihut, D., \& Müller, R. D. (1998). Volcanic margin formation and Mesozoic rift propagators in the Cuvier Abyssal Plain off Western Australia. Journal of Geophysical Research, 103, 27135-27149.

Mohriak, W. U., \& Leroy, S. (2013). Architecture of rifted continental margins and break-up evolution: Insights from the South Atlantic, North Atlantic and Red Sea-Gulf of Aden conjugate margins. Geological Society, London, Special Publications, 369, 497-535.

Monteleone, V., Minshull, T. A., \& Marin-Moreno, H. (2019). Spatial and temporal evolution of rifting and continental breakup in the Eastern Black Sea Basin revealed by long-offset seismic reflection data. Tectonics, 38, 2646-2667. https://doi. org/10.1029/2019TC005523

Morley, C. (2016). Major unconformities/termination of extension events and associated surfaces in the South China Seas: Review and implications for tectonic development. Journal of Asian Earth Sciences, 120, 62-86.

Müller, R., Mihut, D., Heine, C., O'Neill, C., \& Russell, I. (2002). Tectonic and volcanic history of the Carnarvon Terrace: Constraints from seismic interpretation and geodynamic modelling. In M. Keep \& S. J. Moss (Eds.), The sedimentary basins of Western Australia (Vol. 3, pp. 719-740). Proceedings West Australian Basins Symposium.

Mutterlose, J. (1992). Biostratigraphy and palaeobiogeography of Early Cretaceous calcareous nannofossils. Cretaceous Research, 13, 167-189.

Partington, M., Aurisch, K., Clark, W., Newlands, I., Phelps, S., Senycia, P., Siffleet, P., \& Walker, T. (2003). The hydrocarbon potential of exploration permits WA-299-P and WA-300-P, Carnarvon Basin: A case study. The APPEA Journal, 43, 339361. https://doi.org/10.1071/AJ02018

Paton, D., Pindell, J., McDermott, K., Bellingham, P., \& Horn, B. (2017). Evolution of seaward-dipping reflectors at the onset of oceanic crust formation at volcanic passive margins: Insights from the South Atlantic. Geology, 45, 439-442. https://doi. org/10.1130/G38706.1

Paumard, V., Bourget, J., Payenberg, T., Ainsworth, R. B., George, A. D., Lang, S., Posamentier, H. W., \& Peyrot, D. (2018). Controls on shelf-margin architecture and sediment partitioning during a syn-rift to post-rift transition: Insights from the Barrow Group (Northern Carnarvon Basin, North West Shelf, Australia). Earth-Science Reviews, 177, 643-677. https://doi.org/10.1016/j. earscirev.2017.11.026
Pérez-Gussinyé, M., Andrés-Martínez, M., Araújo, M., Xin, Y., Armitage, J., \& Morgan, J. (2020). Lithospheric strength and rift migration controls on synrift stratigraphy and breakup unconformities at rifted margins: Examples from numerical models, the Atlantic and South China Sea margins. Tectonics, 39, e2020TC006255. https://doi.org/10.1029/2020TC006255

Peron-Pinvidic, G., Manatschal, G., \& The "IMAGinING RIFTING" Workshop Participants. (2019). Rifted margins: State of the art and future challenges. Frontiers in Earth Science, 7, 218.

Pryer, L., Romine, K., Loutit, T., \& Barnes, R. (2002). Carnarvon basin architecture and structure defined by the integration of mineral and petroleum exploration tools and techniques. The APPEA Journal, 42, 287-309.

Reeve, M. T. (2017). The structural and stratigraphic expression of continental breakup. Imperial College London.

Reeve, M. T., Jackson, C. A. L., Bell, R. E., Magee, C., \& Bastow, I. D. (2016). The stratigraphic record of prebreakup geodynamics: Evidence from the Barrow Delta, offshore Northwest Australia. Tectonics, 35, 1935-1968. https://doi.org/10.1002/2016TC004172

Reeve, M. T., Magee, C., Bastow, I. D., McDermott, C., Jackson, C. A. L., Bell, R. E., \& Prytulak, J. (2021). Nature of the Cuvier Abyssal Plain crust, offshore NW Australia. Journal of the Geological Society, 178, jgs2020-172.

Robb, M. S., Taylor, B., \& Goodliffe, A. M. (2005). Re-examination of the magnetic lineations of the Gascoyne and Cuvier Abyssal Plains, off NW Australia. Geophysical Journal International, 163, 42-55.

Rohrman, M. (2015). Delineating the Exmouth mantle plume (NW Australia) from denudation and magmatic addition estimates. Lithosphere, L445, 441.

Romine, K., \& Durrant, J. (1996). Carnarvon Cretaceous-Tertiary Tie report. Australian Geological Society Organisation.

Skogseid, J., Pedersen, T., Eldholm, O., \& Larsen, B. T. (1992). Tectonism and magmatism during NE Atlantic continental break-up: The Voring Margin. Geological Society, London, Special Publications, 68, 305-320. https://doi.org/10.1144/gsl. sp.1992.068.01.19

Smith, T., Ogg, J., Kelman, A., Abbott, S., \& Bernecker, T. (2015). Towards common stratigraphic frameworks for Australia's offshore hydrocarbon provinces. The APPEA Journal, 2015, 105-112.

Soares, D. M., Alves, T. M., \& Terrinha, P. (2012). The breakup sequence and associated lithospheric breakup surface: Their significance in the context of rifted continental margins (West Iberia and Newfoundland margins, North Atlantic). Earth and Planetary Science Letters, 355, 311-326.

Stagg, H., Alcock, M., Bernardel, G., Moore, A., Symonds, P., \& Exon, N. (2004). Geological framework of the outer Exmouth Plateau and adjacent ocean basins. Geoscience Australia.

Stagg, H., \& Colwell, J. (1994). The structural foundations of the Northern Carnarvon Basin. The sedimentary basins of Western Australia: Proceedings of Petroleum Exploration Society of Australia Symposium, Perth (pp. 349-365).

Symonds, P. A., Planke, S., Frey, O., \& Skogseid, J. (1998). Volcanic evolution of the Western Australian Continental Margin and its implications for basin development. The sedimentary basins of Western Australia 2: Proc. of Petroleum Society Australia Symposium, Perth, WA.

Thompson, N., Hocking, R., Collins, M., Voon, J., \& Middleton, M. (1990). Lower Cretaceous deposition in the southern Northwest 
Shelf. Minerals and Energy Research Institute of Western Australia.

Tindale, K., Newell, N., Keall, J., \& Smith, N. (1998). Structural evolution and charge history of the Exmouth Sub-basin, northern Carnarvon Basin, Western Australia. The sedimentary basins of Western Australia 2: Proc. of Petroleum Society Australia Symposium, Perth, WA (pp. 473-490).

Tucholke, B., Sawyer, D., \& Sibuet, J.-C. (2007). Breakup of the Newfoundland-Iberia rift. Geological Society, London, Special Publications, 282, 9-46.

Veevers, J. (1986). Breakup of Australia and Antarctica estimated as mid-Cretaceous $(95 \pm 5 \mathrm{Ma})$ from magnetic and seismic data at the continental margin. Earth and Planetary Science Letters, 77, 91-99.

White, N., \& McKenzie, D. (1988). Formation of the "steer's head" geometry of sedimentary basins by differential stretching of the crust and mantle. Geology, 16, 250-253.

Willcox, J. B. \& Exon, N. F. (1976). The regional geology of the Exmouth Plateau. The APPEA Journal, 16(1), 1-11.
Xie, X., Ren, J., Pang, X., Lei, C., \& Chen, H. (2019). Stratigraphic architectures and associated unconformities of Pearl River Mouth basin during rifting and lithospheric breakup of the South China Sea. Marine Geophysical Research, 40, 129-144.

\section{SUPPORTING INFORMATION}

Additional supporting information may be found in the online version of the article at the publisher's website.

How to cite this article: Reeve, M. T., Magee, C., Jackson, C. A.-L., Bell, R. E., \& Bastow, I. D. (2022). Stratigraphic record of continental breakup, offshore NW Australia. Basin Research, 00, 1-24. https://doi.org/10.1111/bre.12656 